\title{
How do sustainability standards consider biodiversity?
}

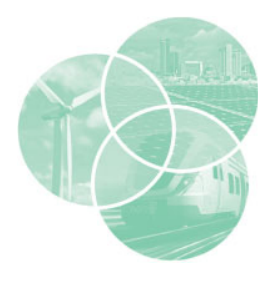

\author{
Oskar Englund* and Göran Berndes
}

Sustainability certification schemes and standards are meant to prevent a range of unacceptable socioeconomic and environmental consequences, such as threats to biodiversity. While there is wide support for conserving biodiversity, operationalizing this support in the form of guiding principles, criteria/indicators, and legislation is complicated. This study investigates how and to what extent 26 sustainability standards (eleven for forest management, nine for agriculture and six biofuel-related) consider biodiversity, by assessing how they seek to prevent actions that can threaten biodiversity as well as how they support actions aimed at biodiversity conservation. For this purpose, a benchmark standard was developed, meant to represent a case with very high ambitions concerning biodiversity conservation. Of the assessed standards, the biofuel-related standards demonstrated the highest level of compliance with the benchmark. On average, they complied with $72 \%$ of the benchmark's component criteria, compared to $61 \%$ for the agricultural standards and $60 \%$ for the forestry standards. Fairtrade, Sustainable Agriculture Network/Rainforest Alliance (SAN/RA), Roundtable on Sustainable Palm Oil (RSPO), and Roundtable on Responsible Soy (RTRS) were particularly stringent, while Green Gold Label S5 (GGLS5), PEOLG, Global Partnership for Good Agricultural Practices (GLOBALGAP), European Union Organic (EU Organic), National Organic Program (NOP), Green Gold Label S2 (GGLS2), and International Sustainability \& Carbon Certification (ISCC) were particularly unstringent. All eleven forestry standards, six of the nine agricultural standards, and all six biofuel-related standards addressed ecosystem conversion, ranging from requiring that high conservation value areas be identified and preserved to requiring full protection. Finally, key barriers to, and challenges for, certification schemes are discussed and recommendations are made for further development of sustainability standards. (C) 2014 John Wiley \& Sons, Ltd.

How to cite this article:

WIREs Energy Environ 2014. doi: 10.1002/wene.118

\section{INTRODUCTION}

$\mathrm{M}$ eeting the increasing demand for biomass-based products without creating unacceptable socioeconomic and environmental consequences is a great challenge. ${ }^{1,2}$ Human societies already use roughly half the planet's land surface, producing biomass with a total energy content equivalent to about $20 \%$ of the

*Correspondence to: oskar.englund@chalmers.se

Division of Physical Resource Theory, Department of Energy and Environment, Chalmers University of Technology, Gothenburg, Sweden

Conflict of interest: The authors have declared no conflicts of interest for this article. total global net primary productivity. ${ }^{3}$ Human land use has caused extensive land degradation and biodiversity loss, as well as emissions to air and water that contribute to, e.g., eutrophication, acidification, stratospheric ozone depletion, and climate change. ${ }^{4-6}$

A growing awareness of the possible size and land use consequences of the rapidly growing bioenergy sector has prompted demands that resources and feedstocks be put to best use and that environmental and social effects of changing production systems (positive and negative) be understood as production grows. ${ }^{7}$ Promotion of bioenergy offers considerable opportunities for the agricultural and forestry sectors, which can find new markets for their products and 
also make economic use of biomass previously considered mere waste. Further, many options exist for developing synergies among different land uses, ${ }^{8,9}$ as well as for shaping land use systems with less impacts on land, water and biodiversity. ${ }^{10-14}$ However, a given objective often conflicts with others. Thus, the development of land use often takes place in the context of trade-offs among more or less incompatible objectives, and promoting sustainable land use realistically requires balancing objectives in terms of environmental and socioeconomic factors. ${ }^{15,16}$

Governance is an essential component of a sustainable energy system. Legislation and regulation as well as sustainability standards and certification schemes are required to guide deployment of bioenergy production systems. Bioenergy feedstock producers in the private sector, as well as governmental and nongovernmental organizations, have taken initiatives to develop criteria/indicators for sustainable biomass production. These can for instance be applied in legislation, such as the EU Renewable Energy Directive (EU-RED), and in sustainability certification schemes. These governance systems can help mitigate negative impacts and promote best management practices, and their use also contributes to shaping the way land is used to produce food and biomaterials.

A variety of generic sustainability certification schemes exist for agriculture and forestry, but they can also be crop-specific or relate to a specific end use of biomass, e.g., bioenergy. In addition, a number of nonoperational sustainability standards exist, which are developed to guide or influence other actors involved in developing operational standards, such as certification schemes or policymakers. Such guidelines have been developed by, e.g., International Tropical Timber Organization (ITTO), for sustainable management of tropical forests; International Federation of Organic Agriculture Movements (IFOAM), for organic agriculture; and the Global Bioenergy Partnership (GBEP), for sustainable bioenergy feedstock production. Many sustainability standards exist, both mandatory and voluntary, and with varying scope. They also differ in how they prioritize different aspects of sustainability. For example, some may be very focused on the environmental performance of a production system, while others focus more on social aspects.

Studies show that there are many challenges associated with the current status of sustainability certification and standards, including the heterogeneity of systems. ${ }^{17-21}$ According to noncertified producers, main barriers include high administrative complexity, high costs, and small market advantages. ${ }^{22,23}$ In addition, stakeholders along bioenergy supply chains may need to comply with different standards to maintain market access and to comply with legislative mandates. Consumers who try to make environmentally conscious purchasing decisions and regulatory agencies and governments involved in enforcing sustainability standards may find it difficult to manage a wide range of systems that use different criteria/indicators. Thus, the proliferation of schemes and standards has lead to confusion among actors involved, market distortion and trade barriers, an increase in commodity costs, and questions about the adequacy of systems in place and how to develop systems that are effective and cost efficient. ${ }^{22,24-26} \mathrm{~A}$ recent study undertaken to monitor the actual implementation process of sustainability certification of bioenergy found that there is no global/common definition of how the sustainability concept should be translated into practice, i.e., how to measure sustainability and which criteria/indicators to use. ${ }^{22}$ The study called for a globally harmonized approach and establishment of a common language, including terminology, to describe sustainability and how it should be verified/documented.

Biodiversity presents a challenge for sustainability certification. While there is wide support for the objective to conserve biodiversity (e.g., the Convention on Biological Diversity has 193 parties and 168 signatures) ${ }^{27}$ operationalization into guiding principles, criteria/indicators, and legislation is complicated. For example, in 2009, the EU-RED established that raw materials used for the production of biofuels and bioliquids may not be produced on land that had the status of highly biodiverse grassland in or after January 2008. At the time of writing (June 2013), the European Commission is still in the process of operationalizing elements of the biofuel sustainability criteria, including clarifying some of the requirements that need to be met with respect to the biodiversity criteria, e.g., in relation to highly biodiverse grasslands.

This article presents an assessment of how biodiversity is considered in different types of sustainability standards. First, biodiversity is defined and strategies for biodiversity conservation are discussed. Then, standards for sustainable production of biomass in agriculture and forestry are evaluated on how they consider biodiversity, i.e., how they attempt to prevent actions that can threaten biodiversity and support actions that can conserve it. It is also assessed how sustainability standards address the conversion of certain ecosystem types. A broad set of standards is included-relating to either (1) sustainable agricultural management; (2) sustainable forest management; or (3) sustainable production of biofuel feedstocks. Similarities and differences within and between the three categories are identified. Finally, key barriers to, 
TABLE 1 | Definition of Biodiversity, Using Four Components

\begin{tabular}{|c|c|c|c|c|}
\hline & Species Diversity & Ecosystem Diversity & Genetic Diversity & Functional Diversity \\
\hline Definition & $\begin{array}{l}\text { The variety of species in an } \\
\text { ecosystem, and their } \\
\text { relative abundance, Refs } \\
28-32\end{array}$ & $\begin{array}{l}\text { The variety of terrestrial and } \\
\text { aquatic ecosystems in a } \\
\text { region, Refs 28-31, } 33\end{array}$ & $\begin{array}{l}\text { The variety of } \\
\text { genetic material } \\
\text { within species, } \\
\text { Refs 28-31, } 34\end{array}$ & $\begin{array}{l}\text { The variety of functional } \\
\text { traits in an ecosystem } \\
\text { (the variety of ways an } \\
\text { ecosystem can respond } \\
\text { to changing conditions) } \\
\text { Refs } 28,30,35\end{array}$ \\
\hline
\end{tabular}

and challenges for, certification schemes are discussed and recommendations are made for further development of sustainability standards.

\section{BACKGROUND}

Biodiversity has been defined in many different ways. Often, it is considered equal to species diversity/richness. However, this is an oversimplification. ${ }^{28}$ The Convention of Biological Diversity (CBD) and the Millennium Ecosystem Assessment (MEA) highlight the complexity of biodiversity by defining it as: 'the variability among living organisms from all sources including, inter alia, terrestrial, marine, and other aquatic ecosystems and the ecological complexes of which they are part; this includes diversity within species, between species and of ecosystems'. ${ }^{29,30}$ CBD describes biodiversity by using three principal levels: ecosystems, species, and genes; the variation within these levels is described with reference to specific concepts, e.g., at the species level, richness, abundance and function. ${ }^{29}$ Here, biodiversity is defined using four components: species diversity, ecosystem diversity, genetic diversity, and functional diversity (Table 1).

Species diversity is what most people associate with the term biodiversity and also the aspect that is most commonly referred to when preservation issues are discussed. ${ }^{28}$ Ecosystem diversity is, along with functional diversity, the most important factor when assessing the stability of an ecosystem at the landscape level. ${ }^{30}$ Genetic diversity refers to the variation at the level of polymorphism in a population. A large genetic diversity gives a better chance to adapt to changing conditions, such as climate change. Some of the individuals in the population are in that case more likely to have allelic variants that are suited for the new conditions and will be able to pass those on to their offspring. ${ }^{31}$ Species that contribute to biogeochemical cycles (e.g. water-, matter-, carbon-, and nitrogen cycling) in similar ways, i.e., that have similar functional traits, are called functionally equivalent species and form functional groups. ${ }^{36}$ An ecosystem with few functional groups and/or with few functionally equivalent species in each group will be more vulnerable to environmental change. Therefore, both the number of functional groups (i.e. the number of functional traits) and the number of functionally equivalent species in each group contribute to functional diversity. Fewer species in general (a decline in species diversity) may result in fewer functionally equivalent species and therefore a decline in functional diversity and higher vulnerability to environmental changes. ${ }^{28,30,35}$

Preservation of unmanaged areas is a common strategy for conserving biodiversity in, e.g., legislation, international agreements, and certification standards. However, what is considered 'natural biodiversity' is in many cases a consequence of centuries of human influence. Cropland and pastures constitute fundamental elements in many landscapes, and the composition of species and ecosystems in such landscapes has successively changed from that of earlier stages, when there was less influence from human activities. ${ }^{29}$ Therefore, it is important to examine how agricultural and forest management can be shaped so as to support biodiversity conservation in production landscapes. Ecoagriculture research is one approach, attempting to clarify how agricultural landscapes can support a higher level of biodiversity, with neutral or even positive effects on agricultural production and livelihoods. ${ }^{37}$ Landscape ecology, ${ }^{38}$ countryside biogeography, ${ }^{39}$ and GIS-based landscape modelling, ${ }^{40}$ are other examples of disciplines and tools that can advance our understanding of interactions between managed and unmanaged areas, and the effects of different production systems on biodiversity. ${ }^{37}$

\section{ASSESSING BIODIVERSITY CONSIDERATIONS IN SUSTAINABILITY STANDARDS}

In order to build on the collective scientific knowledge of sustainability standards in relation to biodiversity and ecosystem services, a review was made of 205 scientific articles (published 2006-2012) that were 
identified based on database searches. ${ }^{a, b, c, d}$ A collection of 35 articles was considered relevant (Table 2). Most of these papers focused on biodiversity; no paper was found with a primary focus on ecosystem services, although in four papers it was jointly or secondarily addressed. Given that biodiversity can be defined in different ways, ${ }^{28}$ it is notable that 16 of the 35 papers did not define or describe biodiversity. Of the remaining papers, four discussed species diversity, one discussed genetic diversity, and the rest of the papers discussed more than one aspect of biodiversity. Furthermore, most of the relevant studies concerned forest management (23/35), primarily in boreal and temperate forests (20/35). Two studies concerned agricultural production systems, and one single study investigated both sectors. The remaining studies primarily concerned cocoa or coffee cultivation. Two papers were particularly relevant: Marjokorpi and Salo ${ }^{60}$ benchmarked eight standards and guidelines for sustainable forest plantation management, applicable in tropical and subtropical regions, against a reference standard based on a categorization of key concepts of biodiversity. Hennenberg et al. ${ }^{70}$ benchmarked forest and agricultural management standards, relevant for bioenergy, against each other.

On the basis of the findings of the review, scope and methodology were developed with the ambition to produce results and insights beyond what was found in the reviewed articles. The assessment includes benchmarking a selection of sustainability standards against a benchmark standard, developed to represent a case with very high ambitions concerning biodiversity conservation, covering main agricultural and forestry related activities that influence biodiversity. This allows for comparisons within a sector-category of standards, as well as between standards categories, i.e., between different sectors.

\section{Selection of Sustainability Standards}

Four different categories of standards were considered: (1) standards for certification of sustainable forest management; (2) standards for certification of sustainable agricultural management; (3) standards for certification of sustainable production of specific crops commonly used as biofuel feedstock; (4) standards for sustainable production of unspecified biofuel feedstock. In addition, guidelines for development or implementation of standards that can be sorted under (1-4) were also considered. A total of 26 standards were selected for the assessment, including 11 forest management standards, 9 agriculture management standards, and 6 biofuel-related standards (Table 3). All selected standards include a set of principles and criteria/indicators, or the equivalent (standards often differ in their terminology), indicating each standard's requirements for production to be considered sustainable or responsible.

\section{Development of the Benchmark Standard}

Sustainability standards should address actions that may cause biodiversity impacts as well as strategies for preventing biodiversity impacts. Agriculture and forestry systems differ concerning the extent to which associated management activities affect biodiversity, but many management practices are common to both (e.g., land clearing and preparation, planting, and harvesting). Specific conservation strategies may also be relevant in both agriculture and forestry. Therefore, actions that negatively affect biodiversity and strategies to protect biodiversity can be formulated so as to be relevant for both agriculture and forest management. Consequently, one general biodiversity-focused benchmark standard was developed for the purpose of facilitating an assessment of the extent to which both agricultural and forestry standards consider the key elements of biodiversity conservation.

Actions that threaten biodiversity include (1) habitat destruction and fragmentation; (2) habitat degradation and modification; (3) overexploitation (including overhunting, and overconsumption of resources necessary for wild species to survive); (4) introduction of nonnative (invasive) species; (5) pollution (including human induced changes in climate); and (6) human population growth (or rather, the corresponding potential increase in resource consumption). ${ }^{31,109,110}$ It should be noted that forest fragmentation is a type of degradation process. But since the reference standard includes criteria covering actions rather than effects of actions, and since it needs to be relevant for both forestry and agriculture, the division of actions as above was judged most suitable.

Conservation biology provides principles and tools for preserving and restoring biodiversity. The general principles developed by the scientific organization Society for Conservation Biology include nine strategies that need to be combined in order to conserve nature. These are: (1) protect species at risk of extinction; (2) designate ecological reserves; (3) lessen the human impact on natural systems; (4) restore ecosystems that have been degraded; (5) augment populations with individuals raised in cultivation or captivity; (6) control the number of individuals harvested in nature; (7) prevent establishment of nonnative species, and eliminate nonnative species that have become established; (8) understand and participate 
TABLE 2 | Studies Investigating Sustainability Standards in Relation to Biodiversity and/or Ecosystem Services

\begin{tabular}{|c|c|c|c|c|c|}
\hline Source & $\begin{array}{l}\text { Type of Land } \\
\text { Management }\end{array}$ & $\begin{array}{c}\text { Primary Focus } \\
\text { (biodiversity or } \\
\text { ecosystem services) }\end{array}$ & $\begin{array}{l}\text { Secondary Focus } \\
\text { (biodiversity or } \\
\text { ecosystem services) }\end{array}$ & $\begin{array}{l}\text { Biodiversity } \\
\text { Aspects }\end{array}$ & Biome \\
\hline Ref 41 & Forest & Biodiversity & - & Unspecified & Boreal \\
\hline Ref 42 & Forest & Biodiversity & - & Unspecified & Global \\
\hline Ref 43 & Forest & - & Biodiversity & Unspecified & Tropical \\
\hline \multicolumn{6}{|l|}{$\operatorname{Ref} 44^{1}$} \\
\hline Ref 45 & Forest & Biodiversity & - & Unspecified & Boreal \\
\hline Ref 46 & Forest & Biodiversity & - & Unspecified & Tropical \\
\hline Ref 47 & Cocoa forest gardens & Biodiversity & Ecosystem services & Species diversity & Tropical \\
\hline Ref 48 & Forest & Biodiversity & - & Species diversity & Tropical \\
\hline Ref 49 & Forest & Biodiversity & - & Unspecified & Boreal \\
\hline Ref 50 & Coffee & - & Biodiversity & Genetic diversity & Tropical \\
\hline Ref 51 & Forest & - & Biodiversity & Unspecified & Boreal \\
\hline Ref 52 & Forest & Both & - & Unspecified & Temperate \\
\hline Ref 20 & Forest & - & Both & Unspecified & Global \\
\hline Ref 53 & Forest & - & Biodiversity & Several & Global \\
\hline Ref 54 & Coffee & Biodiversity & - & Several & Tropical \\
\hline Ref 55 & Coffee & Biodiversity & - & Several & Tropical \\
\hline Ref 56 & Forest & Biodiversity & - & Unspecified & Global \\
\hline Ref 57 & Forest & Biodiversity & - & Several & Boreal \\
\hline Ref 58 & Forest & Biodiversity & $?^{2}$ & $?^{2}$ & Temperate \\
\hline Ref 59 & Forest & $?^{2}$ & $?^{2}$ & $?^{2}$ & Temperate \\
\hline Ref 60 & Forest & Biodiversity & - & Several & Tropical \\
\hline Ref 61 & Forest & Biodiversity & - & Several & Temperate \\
\hline Ref 62 & Forest & Biodiversity & - & Unspecified & Global \\
\hline Ref 63 & Coffee & Biodiversity & - & Species diversity & Tropical \\
\hline Ref 64 & Forest & Biodiversity & - & Species diversity & Boreal \\
\hline Ref 65 & Forest & Biodiversity & - & Several & Boreal \\
\hline \multicolumn{6}{|l|}{ Ref $66^{1}$} \\
\hline Ref 67 & Forest & - & Biodiversity & Several & Tropical \\
\hline Ref 68 & Forest & Both & - & Several & Boreal \\
\hline Ref 69 & Short rotation coppice & - & Biodiversity & Unspecified & Subtropical and temperate \\
\hline Ref 70 & $\begin{array}{l}\text { Bioenergy feedstocks } \\
\text { (forest and agriculture) }\end{array}$ & Biodiversity & Ecosystem services & Unspecified & Global \\
\hline Ref 71 & Agriculture (sugarcane) & - & Biodiversity & Unspecified & Subtropical \\
\hline Ref 72 & Agriculture & - & Biodiversity & Unspecified & Temperate \\
\hline Ref 73 & Coffee & Biodiversity & - & Unspecified & Tropical \\
\hline Ref 74 & Forest & Biodiversity & - & Several & Boreal \\
\hline
\end{tabular}

${ }^{1}$ Paper written in a language of which the authors lack translation capacity.

${ }^{2}$ Unknown. Full text unavailable at the time of assessment. 
TABLE 3 | Overview of Standards Included in the Study

\begin{tabular}{|c|c|c|c|}
\hline Scheme/Organization & Assessed Standard & Abbreviation Used & Type $^{1}$ \\
\hline \multicolumn{4}{|l|}{ Forest management } \\
\hline Forest Stewardship Council & $\begin{array}{l}\text { FSC Principles and Criteria For Forest Stewardship (FSC-STD-01-001 v.4-0 EN), } \\
\text { Ref } 75\end{array}$ & FSC & 1 \\
\hline Sustainable Forestry Initiative & Requirements For The SFI 2010-2014 Program, Ref $76^{5}$ & SFI & 1 \\
\hline Finnish Forest Certification System & $\begin{array}{l}\text { FFCS 1002-3:2003, Criteria for Certification of Holdings of Individual Forest } \\
\text { Owners (FFCS 2003), Ref } 77^{5}\end{array}$ & FFCS & 1 \\
\hline Malaysian Timber Certification System & MC\&I(2002) and MC\&I(Forest Plantations), ${ }^{5}$ Refs $78,79^{4}$ & MTCS & 1 \\
\hline Canadian Standards Association & Z809-08 Sustainable Forest Management, Ref $80^{5}$ & CSA-SFM & 1 \\
\hline Green Gold Label & GGLS5 - Forest Management Criteria, Ref 81 & GGLS5 & 1 \\
\hline Naturland & Naturland Standards for Organic Forest Management, Ref 82 & Naturland Forest & 1 \\
\hline $\begin{array}{l}\text { International Tropical Timber } \\
\text { Organization }\end{array}$ & $\begin{array}{l}\text { Revised ITTO criteria and indicators for the sustainable management of tropical } \\
\text { forests, Ref } 83\end{array}$ & ITTO & 5 \\
\hline African Timber Organization/ITTO & $\begin{array}{l}\text { ATO/ITTO principles, criteria, and indicators for the sustainable management of } \\
\text { African natural tropical forests, Ref } 84\end{array}$ & ATO/ITTO & 5 \\
\hline $\begin{array}{l}\text { ITTO/International Union for } \\
\text { Conservation of Nature }\end{array}$ & $\begin{array}{l}\text { ITTO/IUCN guidelines for the conservation and sustainable use of biodiversity in } \\
\text { tropical timber production forests, Ref } 85\end{array}$ & ITTO/IUCN & 5 \\
\hline $\begin{array}{l}\text { Ministerial Conference on the } \\
\text { Protection of Forests in Europe }\end{array}$ & $\begin{array}{l}\text { (1) ANNEX } 1 \text { OF THE RESOLUTION L2: Pan-European Criteria and Indicators for } \\
\text { Sustainable Forest Management; (2) Improved Pan-European Indicators for } \\
\text { Sustainable Forest Management, Refs } 86,87\end{array}$ & PEOLG & 5 \\
\hline \multicolumn{4}{|l|}{ Agricultural management } \\
\hline $\begin{array}{l}\text { Global Partnership for Good } \\
\text { Agricultural Practices }\end{array}$ & $\begin{array}{l}\text { Control Points and Compliance Criteria (1) All Farms Base, (2) Crops Base, (3) } \\
\text { Combinable Crops, Refs 88-904 }\end{array}$ & GLOBALGAP & 2 \\
\hline KRAV - Swedish Organic Agriculture & Regler för KRAV-certifierad produktion januari 2011, Ref $91^{4}$ & KRAV & 2 \\
\hline European Union & $\begin{array}{l}\text { (1) Council Regulation (EC) No 834/2007 of } 28 \text { June 2007; (2) Commission } \\
\text { Regulation (EC) No 1235/2008 of } 8 \text { December 2008; (3) Commission } \\
\text { Regulation (EC) No 889/2008 of } 5 \text { September 2008, Refs 92-94 }\end{array}$ & EU Organic & 2 \\
\hline $\begin{array}{l}\text { United States Department of } \\
\text { Agriculture }\end{array}$ & National Organic Program, Ref 95 & USDA-NOP & 2 \\
\hline Green Gold Label Agricultural Source & GGLS2: Agricultural Source Criteria, Ref 96 & GGLS2 & 2 \\
\hline Fairtrade & Fairtrade Standard for small producer organizations, Ref 97 & Fairtrade & 2 \\
\hline Naturland & Naturland standards on Production (2011), Ref 98 & Naturland production & 2 \\
\hline $\begin{array}{l}\text { International Federation of Organic } \\
\text { Agriculture Movements }\end{array}$ & The IFOAM Norms for Organic Production and Processing, version 2005, Ref $99^{2}$ & IFOAM & 5 \\
\hline $\begin{array}{l}\text { Sustainable Agriculture } \\
\text { Network/Rainforest Alliance }\end{array}$ & Sustainable Agriculture Standard, version 2, Ref 100 & SAN/RA & 2 \\
\hline \multicolumn{4}{|l|}{ Biofuel related } \\
\hline Roundtable on Sustainable Palm Oil & RSPO Principles and Criteria for Sustainable Palm Oil Production, 2007, Ref $101^{3}$ & RSPO & 3 \\
\hline Roundtable on Responsible Soy & $\begin{array}{l}\text { (1) RTRS Standard for Responsible Soy Production Version 1.0; (2) RTRS EU-RED } \\
\text { Compliance Requirements for Producers, version 3.0, Refs 102, 1033 }\end{array}$ & RTRS & 3 \\
\hline Bonsucro & $\begin{array}{l}\text { Bonsucro Production Standard Including Bonsucro EU Bonsucro Production } \\
\text { Standard, 2011, Ref } 104^{3,4}\end{array}$ & Bonsucro & 3 \\
\hline Roundtable on Sustainable Biofuels & $\begin{array}{l}\text { (1) Consolidated RSB EU-RED Principles \& Criteria for Sustainable Biofuel } \\
\text { Production; (2) Indicators of Compliance For the RSB EU-RED Principles \& } \\
\text { Criteria, Refs 105, } 106^{3}\end{array}$ & RSB & 4 \\
\hline $\begin{array}{l}\text { International Sustainability \& Carbon } \\
\text { Certification }\end{array}$ & $\begin{array}{l}\text { ISCC 11-03-15 V 2.3: EU Sustainability Requirements for the Production of } \\
\text { Biomass, Ref } 107^{3}\end{array}$ & ISCC & 4 \\
\hline Greenergy & Greenergy Brazilian Bioethanol verification programme, Ref $108^{3}$ & Greenergy & 3 \\
\hline
\end{tabular}


in the policy-making process; and (9) educate others about the importance of conservation. ${ }^{109,111}$

The benchmark standard was developed using seven principles based on the above described threats and strategies, under which 26 criteria were defined and sorted (Table 4). The criteria were intended to translate the broadly formulated principles into concrete actions applicable to both agriculture and forest management. The development of the benchmark criteria was supported by the literature review and a pre-assessment of the standards selected for assessment, in order to ensure a compatible format. This pre-assessment also ensured that all biodiversity related principles, criteria/indicators, and potential guidance for compliance in the assessed standards were covered by suitable benchmark criteria.

The selected standards were individually compared with the benchmark standard and for each benchmark criterion it was determined whether a specific standard was compliant or not. In addition, based on the specifics of compliance with the criteria sorted under a given principle, each standard was given a numerical value for that principle, reflecting the degree to which the standard considers the principle (0: principle disregarded; 1 : principle considered in part; 2 : principle fully considered, cf. Table 4). The overall biodiversity stringency of a given standard was finally obtained by summing the compliance values given for all seven principles, for that standard. Standards reaching a sum of 10 or more were classified as Stringent, and standards reaching a sum of six or less were classified as Unstringent.

\section{Assessment of Ecosystem Conversion}

Given that land conversion may induce adverse effects on biodiversity, it was investigated how the standards addressed conversion of certain types of ecosystems, namely: (1) tropical and subtropical forests; (2) temperate forests; (3) boreal forests; (4) wetlands; (5) grass-, shrub- and woodlands; and (6) degraded land. A pre-assessment was performed for the purpose of identifying how the standards address conversion of natural ecosystems, in general terms. It showed that the assessed standards address land conversion in four principal ways: protecting (no production allowed); restricting (production is allowed, provided that properties of ecosystems are not altered); encouraging (production on certain lands is encouraged); and requiring a high conservation value (HCV) assessment (restricting production on, or fully protecting, HCV land). All standards were then assessed to clarify how they address conversion of the ecosystem types given above (i.e., by either protecting, restricting, encouraging, or requiring an $\mathrm{HCV}$ assessment).

\section{ASSESSMENT OUTCOME}

Below, the degree of compliance with criteria, the overall consideration of principles, and the stringency of the assessed standards are presented. The results for the three categories of standards are then compared. Finally, the results of the ecosystem conversion assessment are presented.

\section{Standards for Sustainable Forest Management}

On average, the 11 assessed forestry standards comply with $60 \%$ of the relevant benchmark criteria, complying with 8 (Green Gold Label S5; GGLS5) to 19 (Naturland) of the 25 criteria (Table 5).

Benchmark criteria that were well considered overall by these standards (i.e., criteria where at most one of the assessed standards failed to reach compliance) include those related to (1) endangered species within the production area; (2) habitat destruction; (3) HCV areas; (4) water resources; (5) erosion; (6) soil quality; and (7) long-term sustainability.

Fewer than half of the assessed forestry standards reached compliance with criteria related to: (1) pesticide application; (2) fertilization (3) waste management; (4) recycling; (5) invasive species; (6) GMOs; (7) energy use; (8) fossil energy; (9) research; and (10) awareness.

Four principles are poorly considered overall by the assessed forestry standards. Only one standard fully complies with Energy use and GHG emissions; only two standards fully comply with Habitat degradation and modification and Invasive species and GMOs; and only three standards fully comply with Research, awareness, and education. Overall, the standards comply well with the principles Endangered species, Habitat destruction and fragmentation, and Overexploitation (Table 6).

The results indicate that Forest Stewardship Council (FSC), Sustainable Forestry Initiative (SFI), Malaysian Timber Certification System (MTCS), Naturland, and International Tropical Timber Organization and International Union for Conservation of Nature (ITTO/IUCN) are Stringent, from a biodiversity perspective. GGLS5 and PEOLG are Unstringent (Tables 5 and 6).

\section{Standards for Sustainable Agriculture}

On average, the nine assessed agricultural standards comply with $61 \%$ of the benchmark criteria, complying with 7 (Green Gold Label S2; GGLS2) to 23 (Fairtrade) of the 25 criteria (Table 7).

Benchmark criteria that were well considered overall by these standards (i.e., criteria where at most 
TABLE 4 | Reference Standard Used for Benchmarking of Selected Standards (benchmark standard)

\begin{tabular}{ll}
\hline Principles & Criteria \\
\hline $\begin{array}{l}\text { 1. Endangered species: Threatened and endangered } \\
\text { species shall be preserved, within and around the } \\
\text { production area. }\end{array}$ & $\begin{array}{c}\text { 1.1. Threatened and endangered species with } \\
\text { the production area shall be identified and } \\
\text { protected } \\
\text { 1.2. T Threatened and endangered species } \\
\text { around the production area shall be } \\
\text { considered }\end{array}$ \\
$\begin{array}{ll}\text { 2. Habitat destruction and fragmentation: All parts of } \\
\text { the production chain shall be managed in such a way } \\
\text { that the destruction and fragmentation of natural }\end{array}$ & $\begin{array}{c}\text { 2.2. Specific strategies for avoiding habitat } \\
\text { fragmentation need to be applied }\end{array}$ \\
habitats is minimized. & $\begin{array}{c}\text { 2.3. HCV areas need to be identified and } \\
\text { preserved }\end{array}$
\end{tabular}

3. Habitat degradation and modification: All chemicals 3.1. The use of chemicals for pest management and fertilizers as well as the production techniques in the entire production chain, shall be chosen in such ways that they do not contribute to the degradation and modification of habitats around the production area or the alteration of functional diversity in and around the production area.

4. Overexploitation: The production system shall be managed sustainably over time. Overharvesting of production species shall be avoided and soil fertility maintained.

5. Invasive species and GMOs: Exotic species or GMOs shall not be used, in order to avoid disturbing natural ecosystems and the genetic diversity in populations of native species.

6. Energy use and GHG emissions: Net GHG emissions from biomass production shall be neutral or negative. Therefore, energy use needs to be minimized, fossil fuels avoided and the natural carbon stock maintained or enhanced.

7. Research, awareness, and education: Improvements in biodiversity conservation are dependent on continuous research and increased environmental awareness among consumers and people living in or near sensitive ecosystems. Proper education for workers is key for successful implementation of certification criteria. (pesticides) is restricted, to avoid substances that can be harmful for untargeted species. A list of prohibited chemicals should be provided.

3.2. Guidance for pesticide application is provided, to avoid contamination of surrounding terrestrial and aquatic ecosystems

3.3. Guidance for fertilization is provided, to minimize nutrient leaching to surrounding terrestrial and aquatic ecosystems

3.4. Buffer zones are required to protect watercourses

3.5. Water resources protected

3.6. Soil erosion prevented

3.7. Soil quality maintained

3.8. Waste management applied

3.9. Recycling applied

4.1. Long-term sustainability considered

4.2. Sustainable harvest rates identified and applied

\subsection{Crop-rotation applied}

5.1. Native species preferred over exotic

5.2. Measures taken to prevent introduction of invasive species

\subsection{GMOs prohibited}

6.1. Energy use minimized

6.2. Fossil energy avoided ${ }^{2}$

6.3. Carbon stock maintained or enhanced

7.2. Awareness spread

7.3. Education to workers provided
7.1. Research supported
$2.1-2.3$

At least one

At least six of At least four of 3.1-3.7 3.1-3.7

All relevant ${ }^{1} \quad$ At least one relevant ${ }^{1}$

At least one

At least one

At least one

GHG, Greenhouse gas; GMO, Genetically modified organism; HCV, high conservation value.

1 ' 4 .2 Sustainable harvest rates' relevant for forest management; ' 4.3 crop rotation' relevant for agricultural management.

${ }^{2}$ Should not be interpreted as fossil fuels are prohibited-but that producers are encouraged to avoid them. 


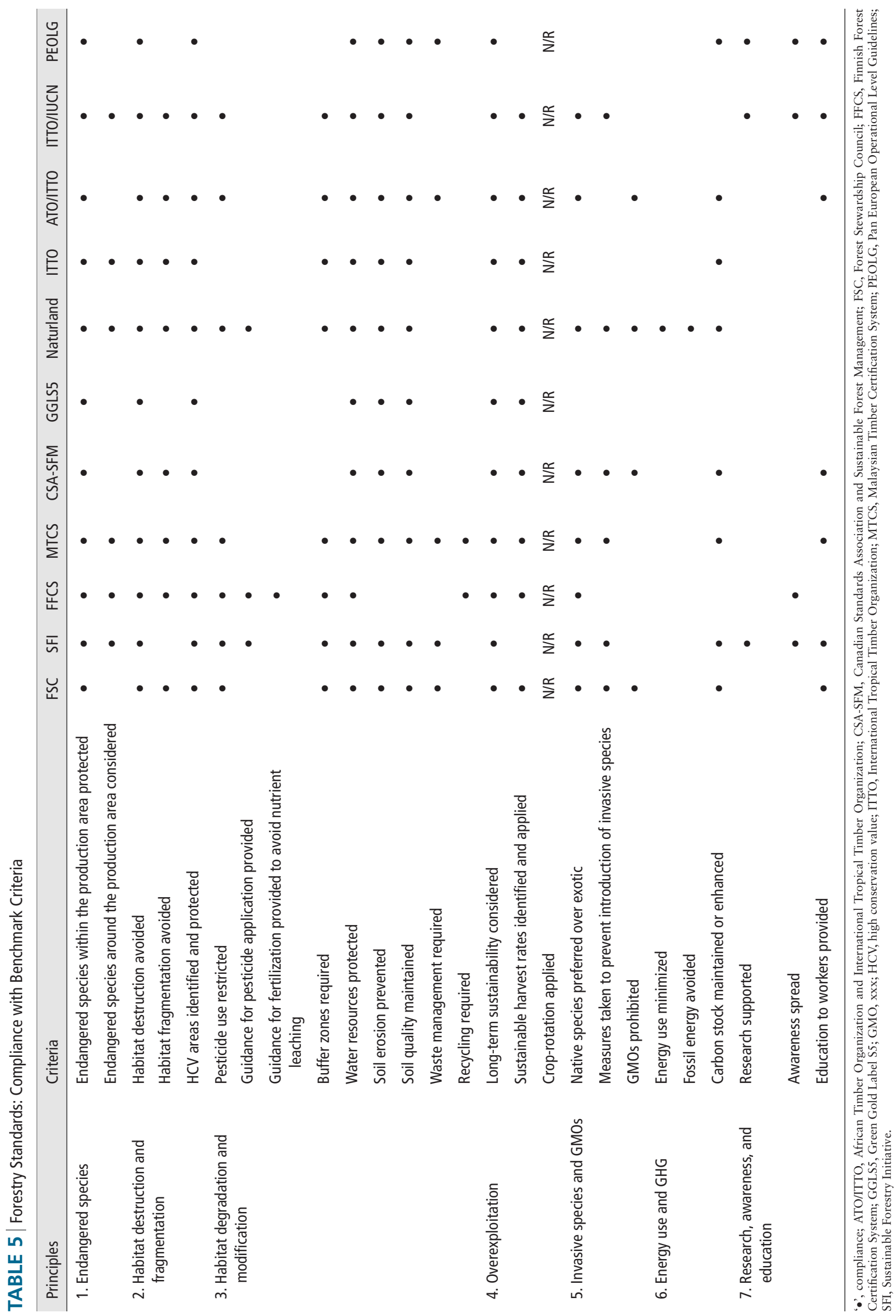


TABLE 6 | Forestry Standards: Compliance with Benchmark Principles

\begin{tabular}{|c|c|c|c|c|c|c|c|c|c|c|c|}
\hline Principles & FSC & SFI & FFCS & MTCS & CSA-SFM & GGLS5 & Naturland & ITTO & ATO/ITTO & ITTO/IUCN & PEOLG \\
\hline 1. Endangered species & $+1-$ & + & + & + & $+1-$ & $+1-$ & + & + & $+1-$ & + & $+1-$ \\
\hline $\begin{array}{l}\text { 2. Habitat destruction and } \\
\text { fragmentation }\end{array}$ & + & $+1-$ & + & + & + & $+/-$ & + & + & + & + & $+1-$ \\
\hline $\begin{array}{l}\text { 3. Habitat degradation and } \\
\text { modification }\end{array}$ & $+1-$ & + & $+1-$ & $+1-$ & - & - & + & $+1-$ & $+1-$ & $+1-$ & - \\
\hline 4. Overexploitation & + & $+1-$ & + & + & + & + & + & + & + & + & $+1-$ \\
\hline $\begin{array}{l}\text { 5. Invasive species and } \\
\text { GMOs }\end{array}$ & + & $+1-$ & $+1-$ & $+1-$ & + & - & + & - & $+1-$ & $+1-$ & - \\
\hline 6. Energy use and GHG & $+1-$ & $+1-$ & - & $+l-$ & $+1-$ & $+1-$ & + & $+1-$ & $+l-$ & - & $+l-$ \\
\hline $\begin{array}{l}\text { 7. Research, awareness, } \\
\text { and education }\end{array}$ & $+1-$ & + & $+1-$ & $+1-$ & $+1-$ & - & - & - & $+1-$ & + & + \\
\hline
\end{tabular}

ATO/ITTO, African Timber Organization and International Tropical Timber Organization; CSA-SFM, Canadian Standards Association and Sustainable Forest Management; FSC, Forest Stewardship Council; FFCS, Finnish Forest Certification System; GGLS5, Green Gold Label; GHG, xxx; GMO, xxx; ITTO, International Tropical Timber Organization; MTCS, Malaysian Timber Certification System; PEOLG, xxx; SFI, Sustainable Forestry Initiative.

Green color $(+)$ indicates considered; yellow color $(+/-)$ indicates partly considered; orange color $(-)$ indicates disregarded.

one of the assessed standards failed to reach compliance) include those related to (1) habitat destruction; (2) pesticide use; (3) fertilization; (4) water resources; (5) erosion; (6) soil quality; (7) waste management; (8) long-term sustainability; and (9) crop rotation.

Fewer than half of the assessed standards reached compliance with criteria related to: (1) endangered species within the production area; (2) endangered species around the production area; (3) habitat fragmentation; (4) native species; (5) invasive species; (6) energy use; (7) fossil energy; (8) carbon stock; (9) research; and (10) education.

Four principles are poorly considered overall by the assessed agricultural standards. No standard fully complies with Invasive species and GMOs, and only two standards comply fully with Endangered species, Energy use, and GHG emissions and Research, awareness, and education, respectively. Overall, the standards comply well with Overexploitation and Habitat degradation and modification, and the same can be seen for Habitat destruction and fragmentation, although to a lesser extent (Table 8).

The results indicate that Fairtrade, Sustainable Agriculture Network/Rainforest Alliance (SAN/RA), Naturland, and KRAV are Stringent, from a biodiversity perspective. Global Partnership for Good Agricultural Practices (GLOBALGAP), European Union Organic (EU Organic), National Organic Program (NOP), and GGLS2 are Unstringent (Tables 7 and 8).

\section{Biofuel-Related Sustainability Standards}

On average, the assessed biofuel-related standards comply with $72 \%$ of the benchmark criteria, complying with 13 (International Sustainability \& Carbon
Certification; ISCC) to 21 (Roundtable on Responsible Soy; RTRS) of the 25 criteria (Table 9).

Benchmark criteria that were well considered overall by these standards (i.e., criteria where at most one of the assessed standards failed to reach compliance) include those related to (1) endangered species within the production area; (2) habitat destruction; (3) HCV areas; (4) pesticide use; (5) pesticide application; (6) buffer zones; (7) water resources; (8) erosion; (9) soil quality; waste management; (10) long-term sustainability; (11) invasive species; and (12) carbon stock.

Fewer than half of the assessed standards reached compliance with criteria related to: (1) native species; (2) GMOs; (3) fossil energy; (4) research; and (5) education.

Two principles are poorly considered overall by the assessed biofuel-related standards. No standard fully complies with Invasive species and GMOs or with Research, awareness, and education. Overall, the standards comply well with Endangered species, Habitat destruction, and fragmentation, Habitat degradation and modification and Overexploitation (Table 10).

The results indicate that Roundtable on Sustainable Palm Oil (RSPO), RTRS, Bonsucro, and Greenergy are Stringent, from a biodiversity perspective. ISCC is Unstringent (Table 9 and 10).

\section{Comparison of Outcomes for the Three Categories of Standards}

The assessed biofuel-related standards reached the highest level of compliance, complying on average with $72 \%$ of the benchmark criteria, compared to 


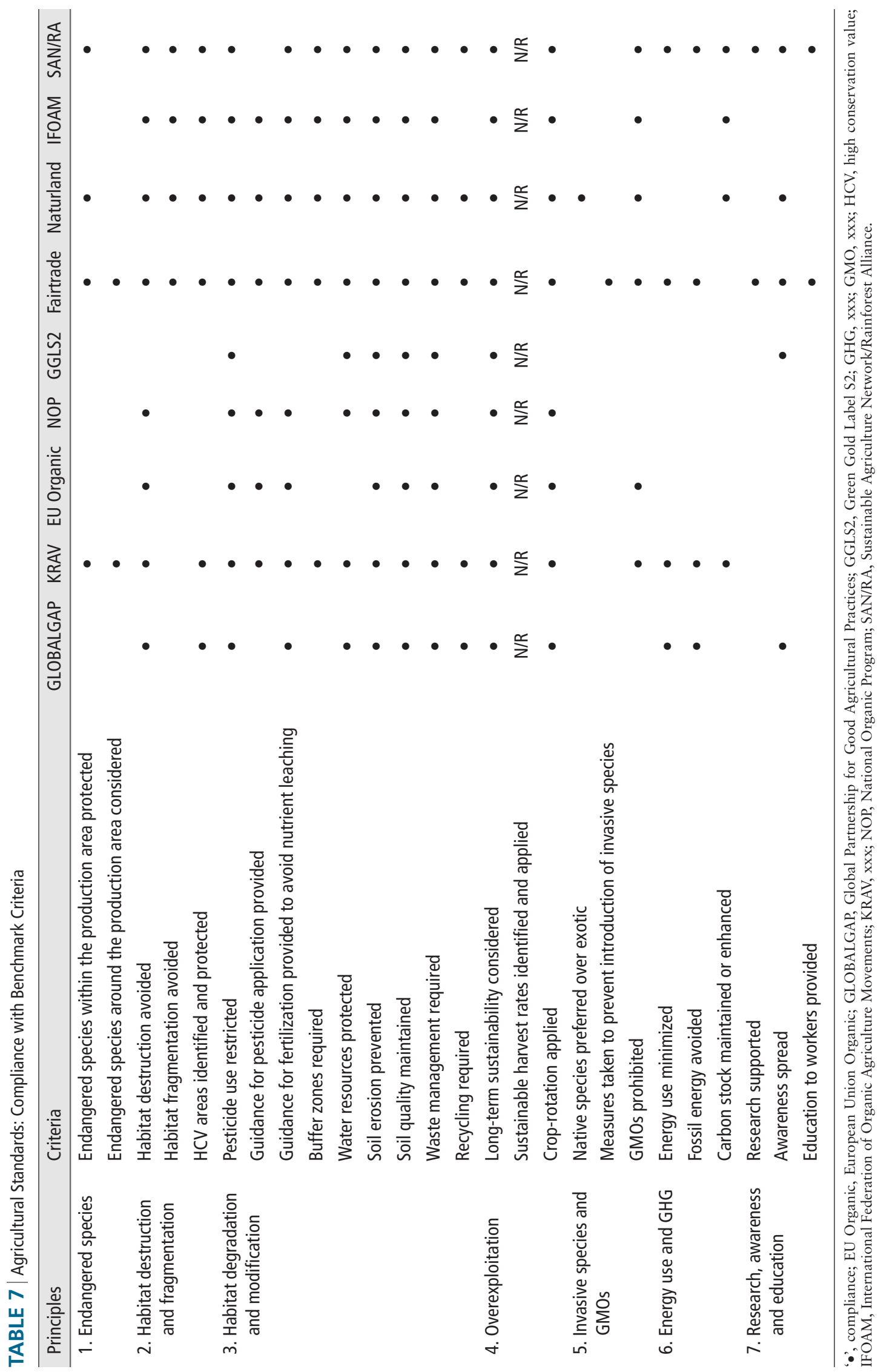


TABLE 8 | Agricultural Standards: Compliance with Benchmark Principles

\begin{tabular}{|c|c|c|c|c|c|c|c|c|c|}
\hline Principles & GLOBALGAP & KRAV & EU Organic & NOP & GGLS2 & Fairtrade & Naturland & IFOAM & SAN/RA \\
\hline 1. Endangered species & - & + & - & - & - & + & $+1-$ & - & $+1-$ \\
\hline $\begin{array}{l}\text { 2. Habitat destruction and } \\
\text { fragmentation }\end{array}$ & $+1-$ & $+1-$ & $+1-$ & $+1-$ & - & + & + & + & + \\
\hline $\begin{array}{l}\text { 3. Habitat degradation and } \\
\text { modification }\end{array}$ & $+1-$ & + & $+1-$ & + & + & + & + & + & + \\
\hline 4. Overexploitation & + & + & + & + & $+1-$ & + & + & + & + \\
\hline 5. Invasive species and GMOs & - & $+1-$ & $+1-$ & - & - & $+1-$ & $+1-$ & $+1-$ & $+1-$ \\
\hline 6. Energy use and GHG & $+1-$ & + & - & - & - & $+l-$ & $+l-$ & $+l-$ & + \\
\hline $\begin{array}{l}\text { 7. Research, awareness, and } \\
\text { education }\end{array}$ & $+l-$ & - & - & - & $+l-$ & + & $+l-$ & - & + \\
\hline
\end{tabular}

EU Organic, European Union Organic; GLOBALGAP, Global Partnership for Good Agricultural Practices; GGLS2, Green Gold Label S2; GHG, xxx; GMO, xxx; IFOAM, International Federation of Organic Agriculture Movements; KRAV, xxx; NOP, National Organic Program; SAN/RA, Sustainable Agriculture Network/Rainforest Alliance.

Green color $(+)$ indicates considered; yellow color (+/-) indicates partly considered; orange color $(-)$ indicates disregarded.

$61 \%$ for the agricultural standards and $60 \%$ for the forestry standards. There are large variations between the standards categories regarding compliance with some benchmark criteria (Table 11, Figure 1). In some cases (e.g., guidance for fertilization), this can be explained by the differences between forest management and agricultural management. In other cases (e.g., preferred use of native species), the reason is less clear. Criteria that were well considered across all three standards categories include those related to (1) habitat destruction; (2) water resources; (3) soil erosion; (4) soil quality; and (5) long-term sustainability. Overall poorly considered criteria include those related to (1) fossil energy and (2) support for research.

Further, the forestry and biofuel-related standards are generally more stringent than the agricultural standards regarding endangered species, both within and around the production area. The same result was found for habitat fragmentation and requirements for HCV assessments. This is reasonable for forestry standards, since forests subject to some degree of management typically host natural ecosystems to a larger degree than agriculture. It was less expected that biofuel-related standards would differ from agricultural standards, since most of the assessed biofuel-related standards refer to agriculture to a higher degree than to forestry.

The agricultural and biofuel-related standards are somewhat more stringent than the forestry standards concerning the use of pesticides. This is reasonable since pesticides are more commonly used in agriculture than in forestry. In addition, since agricultural products are used for human consumption, pesticides in agriculture may be of higher concern than in forestry. Guidance for pesticide application is more common in the biofuel-related standards than in the agricultural standards, even though several of the biofuel-related standards are not explicitly aimed at agricultural production.

All biofuel-related standards require buffer zones, while the forestry and agricultural standards are less stringent in that regard. Requirements of waste management and recycling are more common in the agricultural and biofuel-related standards than in the forestry standards. This is reasonable since agriculture is more intensive than forestry and thereby uses more material and inputs, and thus causes more waste. All but one of the biofuel-related standards, about half of the forestry standards, and only one of the agricultural standards, require measures to prevent the introduction of invasive species.

Energy use and biospheric carbon stocks are considered to a higher degree in the biofuel-related standards than in the forestry and agricultural standards. Given that GHG emissions reduction should be an important objective in land use in general, this can be considered a weakness in forestry and agricultural standards. Perhaps surprisingly, the biofuel-related standards typically do not promote renewable energy. Spreading awareness is considered to a higher degree in the agricultural and biofuel-related standards than in the forestry standards, while the opposite is the case for education and training of workers.

Habitat destruction and fragmentation and Overexploitation are principles well considered by the assessed forestry standards. Poorly considered principles include Energy use and GHG and Research, awareness, and education (Figure 2). Habitat degradation and modification and Overexploitation are 
TABLE 9 | Biofuel-related Standards: Compliance with Benchmark Criteria

\begin{tabular}{|c|c|c|c|c|c|c|c|}
\hline Principles & Criteria & RSPO & RTRS & Bonsucro & RSB & ISCC & Greenergy \\
\hline \multirow[t]{2}{*}{ 1. Endangered species } & $\begin{array}{l}\text { Endangered species within the production } \\
\text { area protected }\end{array}$ & $\bullet$ & $\bullet$ & $\bullet$ & $\bullet$ & & $\bullet$ \\
\hline & $\begin{array}{l}\text { Endangered species around the } \\
\text { production area considered }\end{array}$ & $\bullet$ & $\bullet$ & $\bullet$ & & & $\bullet$ \\
\hline \multirow{3}{*}{$\begin{array}{l}\text { 2. Habitat destruction and } \\
\text { fragmentation }\end{array}$} & Habitat destruction avoided & - & $\bullet$ & $\bullet$ & $\bullet$ & - & $\bullet$ \\
\hline & Habitat fragmentation avoided & $\bullet$ & $\bullet$ & $\bullet$ & $\bullet$ & & \\
\hline & HCV areas identified and protected & - & $\bullet$ & $\bullet$ & $\bullet$ & $\bullet$ & - \\
\hline \multirow{9}{*}{$\begin{array}{l}\text { 3. Habitat degradation and } \\
\text { modification }\end{array}$} & Pesticide use restricted & $\bullet$ & $\bullet$ & $\bullet$ & $\bullet$ & $\bullet$ & $\bullet$ \\
\hline & $\begin{array}{l}\text { Guidance for pesticide application } \\
\text { provided }\end{array}$ & $\bullet$ & $\bullet$ & $\bullet$ & $\bullet$ & & $\bullet$ \\
\hline & $\begin{array}{l}\text { Guidance for fertilization provided to } \\
\text { avoid nutrient leaching }\end{array}$ & & $\bullet$ & $\bullet$ & & $\bullet$ & \\
\hline & Buffer zones required & $\bullet$ & $\bullet$ & $\bullet$ & $\bullet$ & $\bullet$ & $\bullet$ \\
\hline & Water resources protected & $\bullet$ & $\bullet$ & $\bullet$ & $\bullet$ & $\bullet$ & $\bullet$ \\
\hline & Soil erosion prevented & $\bullet$ & $\bullet$ & $\bullet$ & $\bullet$ & $\bullet$ & $\bullet$ \\
\hline & Soil quality maintained & $\bullet$ & $\bullet$ & $\bullet$ & $\bullet$ & $\bullet$ & $\bullet$ \\
\hline & Waste management required & $\bullet$ & $\bullet$ & $\bullet$ & $\bullet$ & $\bullet$ & $\bullet$ \\
\hline & Recycling required & $\bullet$ & $\bullet$ & $\bullet$ & & $\bullet$ & \\
\hline \multirow[t]{3}{*}{ 4. Overexploitation } & Long-term sustainability considered & $\bullet$ & $\bullet$ & $\bullet$ & $\bullet$ & $\bullet$ & $\bullet$ \\
\hline & $\begin{array}{l}\text { Sustainable harvest rates identified and } \\
\text { applied }\end{array}$ & $N / R$ & $N / R$ & $N / R$ & $\bullet$ & & $N / R$ \\
\hline & Crop-rotation applied & $N / R$ & $\bullet$ & & $\bullet$ & & - \\
\hline \multirow{3}{*}{$\begin{array}{l}\text { 5. Invasive species and } \\
\text { GMOs }\end{array}$} & Native species preferred over exotic & $\bullet$ & & & $\bullet$ & & \\
\hline & $\begin{array}{l}\text { Measures taken to prevent introduction of } \\
\text { invasive species }\end{array}$ & $\bullet$ & $\bullet$ & $\bullet$ & $\bullet$ & & $\bullet$ \\
\hline & GMOs prohibited & & & & & & \\
\hline \multirow[t]{3}{*}{ 6. Energy use and GHG } & Energy use minimized & $\bullet$ & $\bullet$ & $\bullet$ & $\bullet$ & & \\
\hline & Fossil energy avoided & $\bullet$ & $\bullet$ & & & & \\
\hline & Carbon stock maintained or enhanced & $\bullet$ & $\bullet$ & $\bullet$ & $\bullet$ & $\bullet$ & $\bullet$ \\
\hline \multirow{3}{*}{$\begin{array}{l}\text { 7. Research, awareness, } \\
\text { and education }\end{array}$} & Research supported & & & $\bullet$ & & & \\
\hline & Awareness spread & $\bullet$ & - & $\bullet$ & & & \\
\hline & Education to workers provided & & & & & $\bullet$ & $\bullet$ \\
\hline
\end{tabular}

$\bullet$ ', compliance; GHG, xxx; GMO, xxx; HCV, high conservation value; ISCC, International Sustainability \& Carbon Certification; RSPO, Roundtable on Sustainable Palm Oil; RTRS, Roundtable on Responsible Soy; RSB, Roundtable on Sustainable Biofuels.

principles well considered by the assessed agricultural standards. Poorly considered principles include Endangered species, Invasive species and GMOs, Energy use and GHG and Research, awareness, and education (Figure 2). Habitat destruction and fragmentation and Habitat degradation and modification are principles well considered by the assessed biofuel-related standards. Poorly considered principles include Invasive species and GMOs and Research, awareness, and education (Figure 2).

\section{Ecosystem Conversion Assessment}

The ways the assessed standards address conversion of seven main ecosystem types is presented in Table 12. All of the eleven forestry standards address ecosystem conversion. For forested land, conversion is typically regulated by requiring that $H C V$ areas be identified and protected. Exceptions include Naturland (which restricts conversion of forested land), and GGLS5 (which protects forested land from conversion into plantation forest). Among the assessed forestry 
TABLE 10 | Biofuel-Related Standards: Compliance with Benchmark Principles

\begin{tabular}{|c|c|c|c|c|c|c|}
\hline Principles & RSPO & RTRS & Bonsucro & RSB & ISCC & Greenergy \\
\hline 1. Endangered species & + & + & + & $+1-$ & - & + \\
\hline 2. Habitat destruction and fragmentation & + & + & + & + & $+1-$ & $+1-$ \\
\hline 3. Habitat degradation and modification & + & + & + & + & + & + \\
\hline 4. Overexploitation & + & + & $+1-$ & + & $+1-$ & + \\
\hline 5. Invasive species and GMOs & $+1-$ & $+1-$ & $+l-$ & $+1-$ & - & $+l-$ \\
\hline 6. Energy use and GHG & + & + & $+1-$ & $+1-$ & $+1-$ & $+1-$ \\
\hline 7. Research, awareness, and education & $+1-$ & $+1-$ & $+1-$ & - & $+1-$ & $+1-$ \\
\hline
\end{tabular}

GHG, xxx; GMO, xxx; ISCC, International Sustainability \& Carbon Certification; RSPO, Roundtable on Sustainable Palm Oil; RTRS, Roundtable on Responsible Soy; RSB, Roundtable on Sustainable Biofuels.

Green color $(+)$ indicates considered; yellow color $(+/-)$ indicates partly considered; orange color $(-)$ indicates disregarded.

standards, only the ITTO/IUCN standard covers a nonforest ecosystem (wetlands) in its required $\mathrm{HCV}$ assessment- the other standards cover forest ecosystems only. In addition, few of the standards address conversion of nonforested land by other means than requiring HCV assessments: Wetlands are protected by SFI and Naturland, and conversion is restricted by FFCS and PEOLG. Conversion of grass, shrub-, and woodlands is encouraged by PEOLG, while Naturland protects such ecosystem types. The remaining forestry standards do not consider nonforest ecosystems. Thus, in some cases, it may be possible to convert highly biodiverse grasslands or wetlands into certified plantation forests.

Six of the nine agricultural standards address ecosystem conversion (exceptions: EU Organic, NOP, and GGLS2). Contrary to the forestry standards, the agricultural standards that address ecosystem conversion typically do not rely solely on HCV assessments for identifying no-go areas (exception: Fairtrade). Instead, they require that all natural vegetation remain unmanaged. Thus, in some cases (i.e., EU Organic, NOP, and GGLS2), farmers may be able to convert any ecosystem type into certified cropland, while in other cases (i.e., all the other assessed agricultural standards), farmers are basically not able to convert any type of unmanaged land into certified cropland.

All six biofuel-related standards consider ecosystem conversion. While the forestry standards rely on HCV assessments and focus primarily on forested lands, and agricultural standards either protect everything or nothing, the biofuel-related standards consider all the ecosystem types, either by requiring protection or a combination of protection and HCV assessments. RSPO, e.g., protects forested land and wetlands, requires an HCV assessment for grasslands, and encourages conversion of degraded lands. This is likely a direct effect of the sustainability requirements in EU-RED, which state that forested lands, wetlands, and highly biodiverse grasslands are no-go areas for biofuel feedstock production, if the products are to be sold on the EU-RED market. Since all six biofuel-related standards are RED-approved, areas that are no-go according to RED are also no-go areas in these standards.

Overall, five standards encourage restoration of degraded land; three forestry standards (ATO/ITTO, ITTO/IUCN and PEOLG) and two biofuel-related standards (RSPO and RTRS). Four standards protect degraded lands in different ways; one forest standard (Naturland) and three agricultural standards (GLOBALGAP, IFOAM, and SAN/RA). Only one of the five assessed RED-approved standards (RTRS) encourages restoration of degraded land, even though the latter measure is included in RED as an option for earning GHG emissions savings bonuses. This may be explained by the fact that it is not yet possible to earn such bonuses, due to the delay in developing a definition of 'degraded land'.

\section{SUMMARY AND DISCUSSION OF ASSESSMENT OUTCOME}

In summary, the assessed biofuel-related standards had the highest level of compliance with the benchmark standard, complying on average with $72 \%$ of the benchmark criteria, compared to $61 \%$ for the agricultural standards and $60 \%$ for the forestry standards. Fairtrade and SAN/RA (agriculture), and RSPO and RTRS (biofuel) were the most stringent, while GGLS5 and PEOLG (forest), GLOBALGAP, EU Organic, NOP, and GGLS2 (agriculture), and ISCC (biofuel) were the least stringent.

In general, the assessed standards consider habitat destruction, -fragmentation, -degradation, -modification, and overexploitation well, while invasive species and GMOs, research, awareness, and 
TABLE $11 \mid$ Commonly Well Considered Criteria and Commonly Nonconsidered Criteria, for the Three Standard Types, Respectively

\begin{tabular}{|c|c|c|c|c|}
\hline Principles & Criteria & Forest & Agriculture & Biofuels \\
\hline \multirow[t]{2}{*}{ 1. Endangered species } & $\begin{array}{l}\text { Endangered species within the production area } \\
\text { protected }\end{array}$ & + & - & + \\
\hline & $\begin{array}{l}\text { Endangered species around the production area } \\
\text { considered }\end{array}$ & & - & \\
\hline \multirow{3}{*}{$\begin{array}{l}\text { 2. Habitat destruction and } \\
\text { fragmentation }\end{array}$} & Habitat destruction avoided & + & + & + \\
\hline & Habitat fragmentation avoided & & - & \\
\hline & $\mathrm{HCV}$ areas identified and protected & + & & + \\
\hline \multirow{9}{*}{$\begin{array}{l}\text { 3. Habitat degradation and } \\
\text { modification }\end{array}$} & Pesticide use restricted & & + & + \\
\hline & Guidance for pesticide application provided & - & & + \\
\hline & $\begin{array}{l}\text { Guidance for fertilization provided to avoid nutrient } \\
\text { leaching }\end{array}$ & - & + & \\
\hline & Buffer zones required & & & + \\
\hline & Water resources protected & + & + & + \\
\hline & Soil erosion prevented & + & + & + \\
\hline & Soil quality maintained & + & + & + \\
\hline & Waste management required & - & + & + \\
\hline & Recycling required & - & & \\
\hline \multirow[t]{3}{*}{ 4. Overexploitation } & Long-term sustainability considered & + & + & + \\
\hline & Sustainable harvest rates identified and applied & & $\mathrm{N} / \mathrm{R}$ & \\
\hline & Crop-rotation applied & $\mathrm{N} / \mathrm{R}$ & + & \\
\hline \multirow{3}{*}{$\begin{array}{l}\text { 5. Invasive species and } \\
\text { GMOs }\end{array}$} & Native species preferred over exotic & & - & - \\
\hline & $\begin{array}{l}\text { Measures taken to prevent introduction of invasive } \\
\text { species }\end{array}$ & & - & + \\
\hline & GMOs prohibited & - & & - \\
\hline \multirow[t]{3}{*}{ 6. Energy use and GHG } & Energy use minimized & - & - & \\
\hline & Fossil energy avoided & - & - & - \\
\hline & Carbon stock maintained or enhanced & & - & + \\
\hline \multirow{3}{*}{$\begin{array}{l}\text { 7. Research, awareness, } \\
\text { and education }\end{array}$} & Research supported & - & - & - \\
\hline & Awareness spread & - & & \\
\hline & Education to workers provided & & - & - \\
\hline
\end{tabular}

'+', benchmark criteria complied with by all the assessed standards, with one exception allowed; '-', benchmark criteria complied with by less than $50 \%$ of the assessed standards; GHG, xxx; GMO, xxx.

education, and Energy use and GHG are poorly considered.

There are notably large differences in stringency between some standards having a similar scope. For example, IFOAM, which sets the 'norms' for organic agriculture, is significantly more stringent than either EU Organic or NOP. In addition, KRAV endorses EU Organic, even though KRAV classifies as Stringent and EU Organic as Unstringent. Further, the SFI standard, which is a forest industry initiative, shows similar stringency as the FSC standard, which is often regarded as more thorough in its coverage of ecological issues. ${ }^{51}$ Furthermore, the high stringency in the Fairtrade standard, and to some extent also
SAN/RA, was unexpected, as these are perceived to primarily focus on social aspects.

Some of the differences in stringency can be explained by differences concerning biophysical properties or legal contexts in countries or regions in which the standards originate or for which they are intended. For example, standards targeting production in countries that have less stringent environmental legislation and/or limited enforcement capacity-and where agriculture or forestry sectors are still expanding onto natural vegetation-likely need to be more stringent than standards developed for countries where the existing protection of remaining natural ecosystems is effective and where the land 


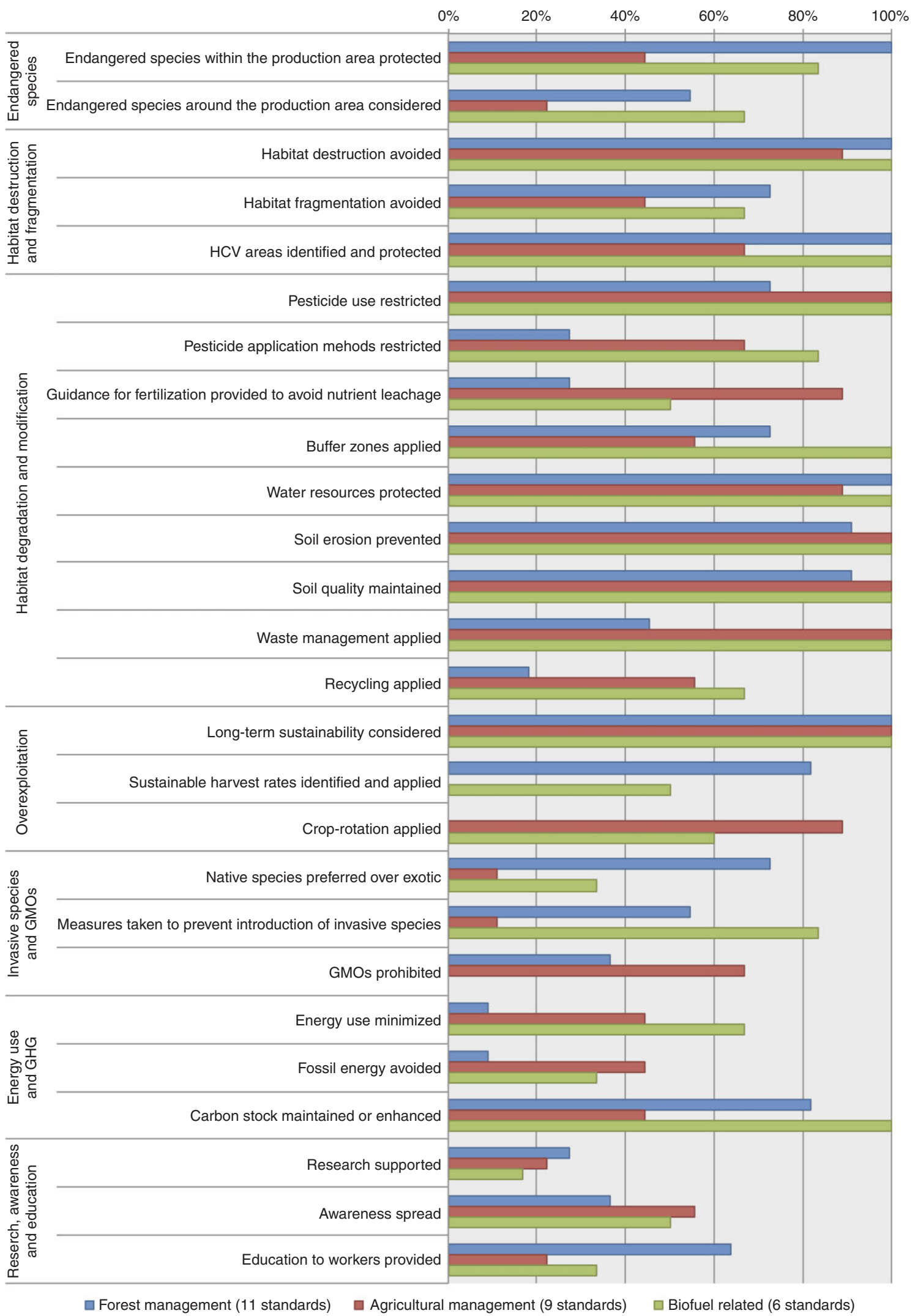

FIG URE 1 | Percentage of benchmark criteria complied with by the three standard types, respectively. 


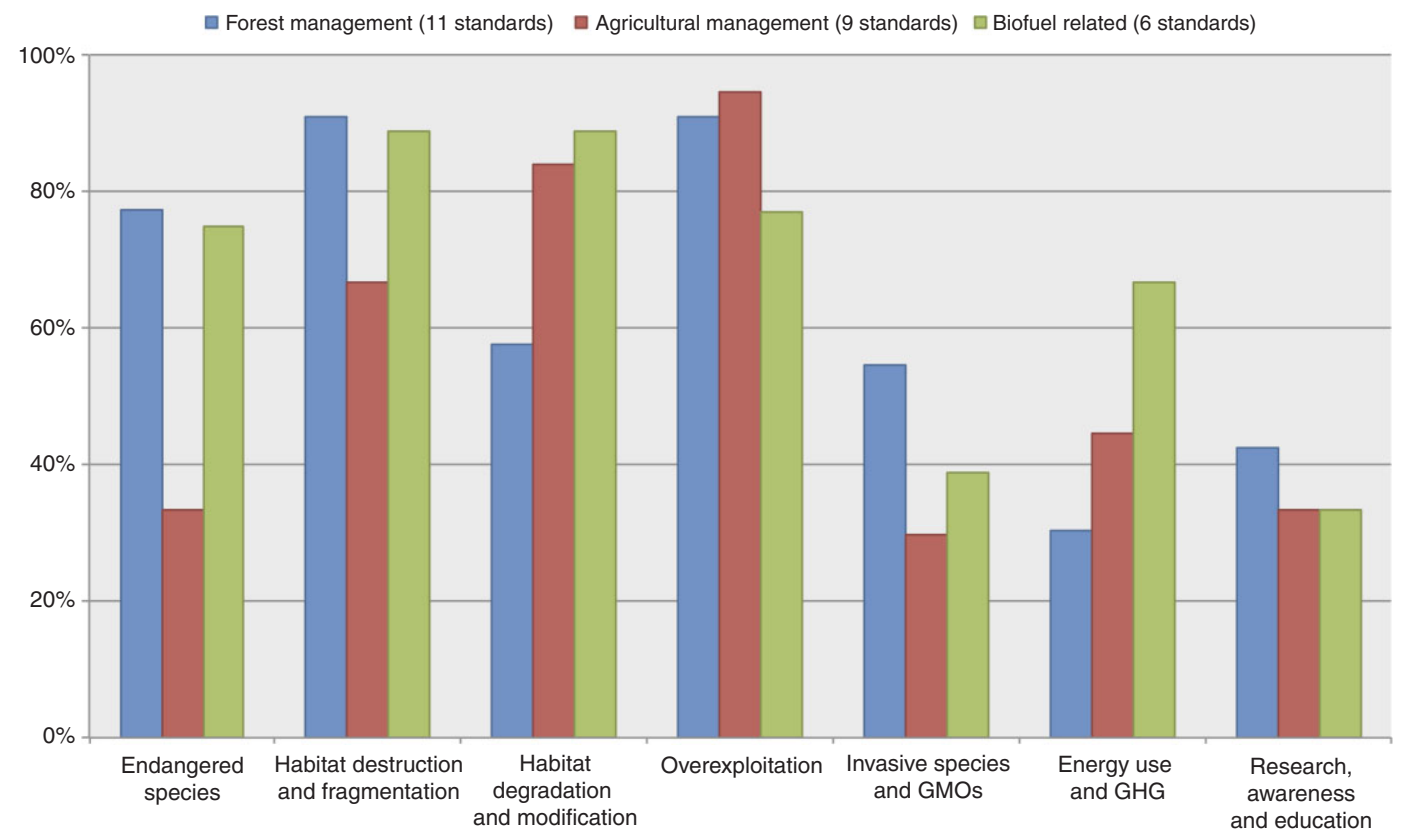

FIGURE 2 | Percentage of benchmark criteria complied with on a principle level for the three standard types, respectively. Well considered principles are those with $>80 \%$ criteria complied with in total; Poorly considered principles are those with $<50 \%$ criteria complied with in total.

conversion pressure is low. Nevertheless, the findings demonstrate that standards that are seemingly similar can be rather heterogeneous, and also that standards perceived as mainly associated with certain aspects can be highly stringent in regard to other aspects.

Regarding ecosystem conversion, forestry standards typically only protect areas that are considered HCV. They also tend to limit the HCV assessment requirements to include forested land only, i.e., they do not prevent conversion of highly biodiverse grasslands or wetlands into certified plantation forests. ${ }^{e}$ Agricultural standards cover more ecosystem types and typically do not provide for much flexibility: specific ecosystem types are either no-go areas or there are no conversion restrictions at all. The inflexibility that several of the agricultural standards apply may result in areas that could be beneficially converted into sustainable cultivation, such as some degraded grasslands, not being available. The biofuel-related standards, as already noted, are influenced by EU-RED and cover ecosystem conversion comprehensively, using a combination of HCV requirements and strict protection measures. Finally, some standards (EU Organic, NOP, and GGLS2) do not restrict land conversion at all. This may not be a large problem in countries with stringent legislation and sufficient enforcement capacity, but in countries where this is lacking, natural vegetation may be converted into certified agriculture, impacting biodiversity.
The fairness of the comparison between forestry and agricultural standards may be questioned, since certain benchmark criteria may be more connected to one type of land use than the other. This was however considered when interpreting the results.

It should be noted that the assessment outcome cannot be used as a basis for understanding the effectiveness of the standards. First, the assessment outcome clarifies whether a particular standard complies with a benchmark criterion, but it does not provide information about how this benchmark criterion is addressed. For instance, one standard may only require that a particular issue be considered, while another standard addresses the same issue by requiring measurements, assessments, monitoring, etc.- - still, both these standards would be assessed as complying with the corresponding benchmark criteria. However, we observed that standards having a high level of compliance with the benchmark criteria are typically also more concrete in their way of addressing them. Second, in order to fully understand the effectiveness of sustainability standards to conserve biodiversity, field studies are necessary to measure actual results. Third, stringent sustainability standards may appear advantageous from a biodiversity perspective, but the effectiveness in conserving biodiversity depends on the relative importance of production under such standards compared to other production. Naturally, stringent certification schemes have to be widely applied in order to have a real effect on biodiversity conservation. 
TABLE 12 | Restrictions in Conversion of Six Ecosystem Types, in the Assessed Standards

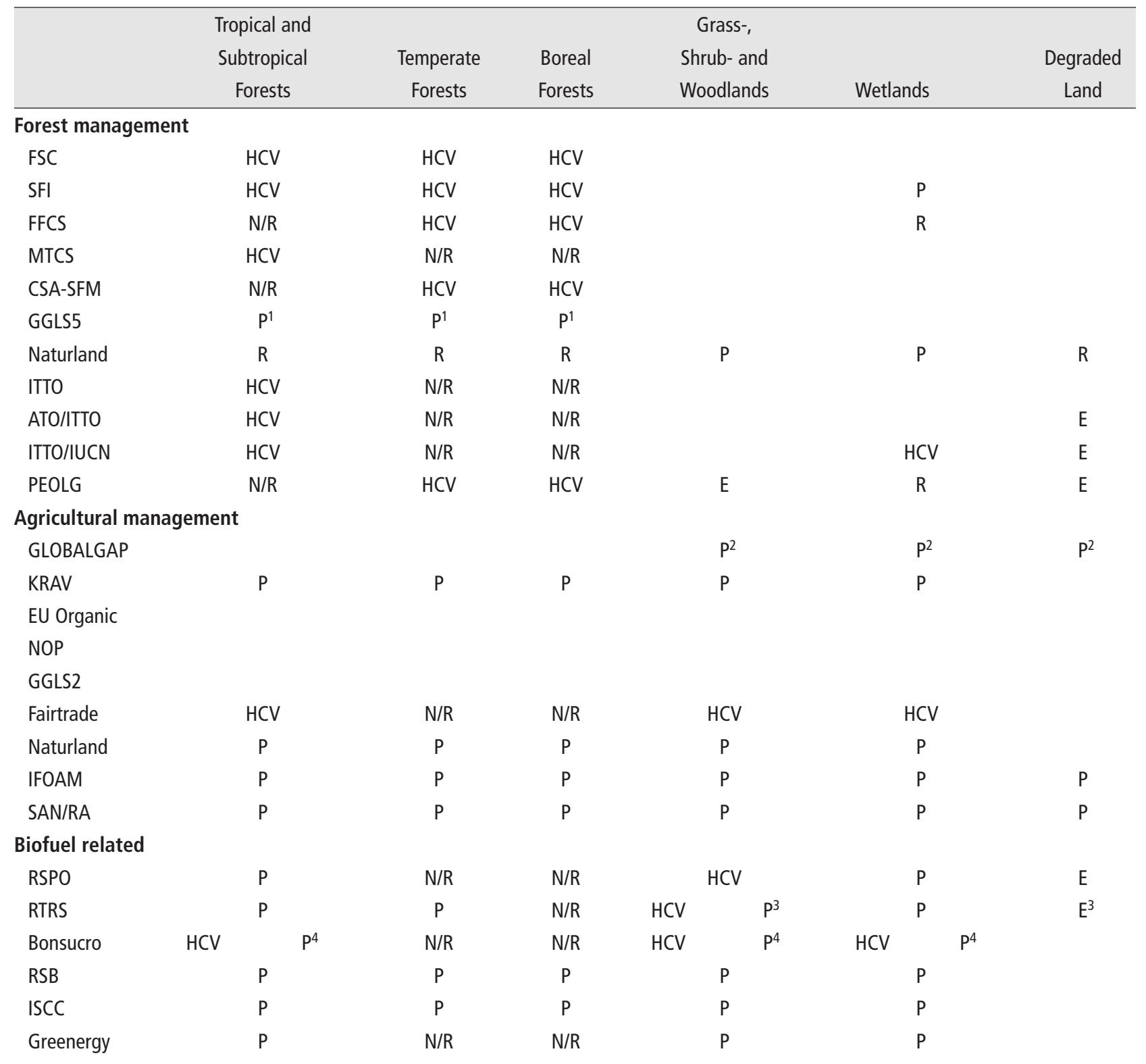

ATO/ITTO, African Timber Organization and International Tropical Timber Organization; CSA-SFM, Canadian Standards Association and Sustainable Forest Management; EU Organic, European Union Organic; FSC, Forest Stewardship Council; FFCS, Finnish Forest Certification System; GGLS5, Green Gold Label S5; GGLS2, Green Gold Label S2; GLOBALGAP, Global Partnership for Good Agricultural Practices; HCV, high conservation value; IITO/IUCN, International Tropical Timber Organization and International Union for Conservation of Nature; ISCC, International Sustainability \& Carbon Certification; KRAV, xxx; MTCS, Malaysian Timber Certification System; PEOLG, xxx; RSPO, Roundtable on Sustainable Palm Oil; RTRS, Roundtable on Responsible Soy; RSB, Roundtable on Sustainable Biofuels; SAN/RA, Sustainable Agriculture Network/Rainforest Alliance; SFI, Sustainable Forestry Initiative.

Besides for 'degraded land', all ecosystem types refer to unmanaged areas. 'P' indicates 'protected'; 'R' indicates 'restricted'; 'E' indicates 'encouraged; 'HCV' indicates that conversion can be allowed, provided that the area is not regarded as HCV; 'N/R' indicates 'not relevant', i.e., the ecosystem type is not affected by the assessed standard.

${ }^{1}$ For establishments of plantations only.

${ }^{2}$ Preservation of 'unproductive' nonforested land is recommended.

${ }^{3}$ To comply with the 'RTRS EU-RED Compliance Requirements for Producers'.

${ }^{4}$ To comply with the 'Bonsucro EU Production Standard'.

Given that certification involves additional costs (e.g., increased production cost, additional administration and fees to the certification scheme, certification body and auditors), biomass production meeting sustainability standards may require support (e.g., establishment of markets for biofuels or other products that are based on such biomass) in order to become established and grow to significant scale. 
However, where such 'premium markets' become established, production complying with more stringent standards may still not become significant in scale if production complying with less stringent standards also meets the requirements associated with the premium market and can support a market price that is too low from the perspective of the more stringent standards. Biofuels and other biomass products may also be produced based on many different feedstocks and some alternatives that comply with stringent standards may outcompete other more costly alternatives complying with the same standard. For example, sugarcane ethanol meeting the EU-RED requirements may outcompete more expensive European cereal ethanol meeting the same requirements. If this happens, EU-RED helps little in protecting biodiversity affected by European cereal production, which would then primarily be associated with food markets.

The biodiversity impact of sustainability standards may be impacted by unintended effects. For example, biomass production complying with sustainability standards may reach lower yields than conventional production (or production under less stringent standards). Ceteris paribus, lower yields mean that more land has to be brought into production to meet the demand and associated land use change may result in biodiversity impacts. ${ }^{43}$

The extent to which sustainability standards protect biodiversity also depends on whether they stimulate innovation in land use aiming at protecting or enhancing biodiversity in the production landscape. Studies indicate that structuring and managing agricultural landscapes to host wild biodiversity can have neutral and even positive effects on agricultural output and livelihoods. ${ }^{37}$ There are many examples of how perennial herbaceous and woody crops can be integrated into existing agricultural landscapes so as to enhance biodiversity and reduce impacts on water and soils. ${ }^{14}$

\section{CONCLUSIONS AND RECOMMENDATIONS}

Standards are not permanent, but they are continuously developed to reflect the state of understanding including availability of data and tools. Some standards are subject to frequent incremental updates while others undergo less frequent but more substantial changes. All the assessed standards can, to a varying degree, be improved to better consider biodiversity. The benchmark standard presented in this paper could be used as one basis in the development of more concrete criteria/indicators that fit into the scope of individual standards. The further development of sustainability standards should aim for increased harmonization and reduction of heterogeneity of systems, while staying relevant for their intended production system. A balance needs to be found between stringency and comprehensiveness on the one hand and feasibility from a biomass-producer perspective on the other hand. It is important to avoid unnecessary requirements that increase administrative burden and cost without improving conservation outcome. Requirements that are too restricting/demanding may slow implementation and even prevent biomass production under the sustainability standard from reaching meaningful scale.

The use of generic standards, which have to be comprehensive in order to cover relevant aspects for a broad set of production systems, could be facilitated by (1) specifying for which production systems a criterion is valid, (2) defining different quantitative requirements for different production systems, or (3) developing substandards for different production systems. Heterogeneity of systems can also be reduced by considering multiple end uses of biomass in individual standards, when appropriate. SAN/RA, e.g., was initially applicable for food products only, but is now endorsed by RSB for production of biofuel feedstock. Consequently, producers can now sell their certified products at a premium on both the food market and the biofuel market, and traders can buy SAN/RA certified products and sell them on the EU-RED market.

Effectively realizing the objective to promote sustainable bioenergy requires flexibility in implementation to reflect local circumstances. In some countries, national legislation may already cover some of the requirements in a standard. If it is recognized that existing national legislation is sufficiently comprehensive and strict—and widely complied with—producers in such a country may be exempted from their reporting obligations concerning these requirements. Transitional rules might be used in situations where immediate full compliance with sustainability requirements is judged unattainable; less stringent initial requirements combined with a plan for development towards full compliance may be preferred where the alternative is more disruptive production for noncertified markets. A concrete example can be seen in the Fairtrade standard, which requires compliance with a basic set of criteria in the first year and then gradually extends compliance requirements to include an increasing number of criteria over time. This approach makes the first step into certification surmountable but, as the entire standard is highly comprehensive, constant improvement inevitable.

Similarly, allowing for some degree of flexibility may also help in addressing certain unwanted 
effects, such as yield losses and nitrogen leaching associated with a transition to certified production and exclusion of suitable lands irrespective of conservation outcome. The possibility to produce for certified markets might be an incentive for developing land development plans balancing protection and production objectives in areas where much of the land is covered by ecosystems that are not allowed to be used under a sustainability standard. Such land development plans-where a certain share of these ecosystems are used for biomass production-might be preferred where the land conversion pressure is high.

The further development of certification standards could also consider approaches to stimulate innovation in land use that contributes positively to biodiversity conservation. Achieving this likely requires involvement of innovative practitioners, scientists, and indigenous land managers that are adapting, designing, and managing diverse types of landscapes to generate positive co-benefits for production, biodiversity, and local people. This work may increasingly need to consider adaptation needs arising as a consequence of climate change. A new role for actors involved with sustainability certification could be to facilitate processes where specific tools are used to engage stakeholders in defining and prioritizing sustainability objectives-including biodiversity conservation-in a specific local/regional context. Initiatives that show how this could take place include, e.g., ToSIA, ${ }^{112}$ and attempts to identify and certify so-called 'low-iLUC' production.

As previously discussed, land management is characterized by trade-offs, and standards therefore need to consider the goals and objectives of different stakeholders in order to be effective. Therefore, it is necessary for standard developers to involve a wide range of stakeholders in the development process. By doing so, a standard can be developed to reach acceptance among all stakeholders, be it NGOs, landowners, biofuel producers, or traders. This process can also contribute to the development of shared views among diverse stakeholders involved in the public debate about bioenergy sustainability in general.

\section{ENDNOTES}

a Scopus database. KEY ((certifi* OR standard*) AND ("diversity OR richness) AND (agricultur" OR forest* OR produc* OR biomass)) AND DOCTYPE $($ ar OR re) AND PUBYEAR > 2005 AND (LIMIT-TO(SUBJAREA, "AGRI"))

${ }^{b}$ Scopus database. KEY ((certifi* OR standard*) AND (ecosystem service* OR ecosystem function*)) AND DOCTYPE(ar OR re) AND PUBYEAR $>2005$ AND (LIMIT-TO(SUBJAREA, "AGRI"))

${ }^{c}$ Web of Science database. Topic $=\left(\left(\left(\right.\right.\right.$ certifi* $\left.^{*}\right)$ AND (biodiversity OR diversity OR richness) AND (agricultur* OR forest* OR biomass))) Refined by: Web of Science Categories $=($ ECOLOGY OR ENVIRONMENTAL SCIENCES OR FORESTRY OR BIODIVERSITY CONSERVATION OR AGRICULTURE MULTIDISCIPLINARY) Timespan $=2006-2012$. Databases $=$ SCI-EXPANDED. Lemmatization $=$ On

${ }^{d}$ Web of Science database. Topic $=(($ certif* AND (ecosystem service* OR ecosystem function*) AND (agricultur* OR forest* OR biomass))) Refined by: Web of Science Categories $=($ ECOLOGY OR ENVIRONMENTAL STUDIES OR AGRONOMY OR FORESTRY OR ENVIRONMENTAL SCIENCES OR BIODIVERSITY CONSERVATION OR AGRICULTURAL ENGINEERING OR MULTIDISCIPLINARY SCIENCES $)$ Databases $=$ SCI-EXPANDED Timespan $=2006$-2012 Lemmatization $=$ On

$e^{e}$ The FSC system is presently under revision to extend the HCV assessment to also cover ecosystem types other than forests.

\section{ACKNOWLEDGMENTS}

The authors are grateful for the very helpful comments from three anonymous reviewers. Financial support from Vattenfall, E.ON and the Swedish Energy Agency are gratefully acknowledged.

\section{REFERENCES}

1. Smith P, Haberl H, Popp A, Erb KH, Lauk C, Harper R, Tubiello FN, de Siqueira PA, Jafari M, Sohi S, et al. How much land-based greenhouse gas mitigation can be achieved without compromising food security and environmental goals? Glob Chang Biol 2013, 19:2285-302.
2. Lambin EF, Meyfroidt P. Global land use change, economic globalization, and the looming land scarcity. Proc Natl Acad Sci USA 2011, 108:3465-72.

3. Haberl H, Erb KH, Krausmann F, Gaube V, Bondeau A, Plutzar C, Gingrich S, Lucht W, Fischer-Kowalski M. Quantifying and mapping 
the human appropriation of net primary production in earth's terrestrial ecosystems. Proc Natl Acad Sci USA 2007, 104:12942-7.

4. Ellis EC. Anthropogenic transformation of the terrestrial biosphere. Philos Trans Roy Soc A Math Phys Eng Sci 2011, 369:1010-35.

5. Steffen W, Crutzen PJ, McNeill JR. The anthropocene: are humans now overwhelming the great forces of nature. Ambio 2007, 36:614-21.

6. Zalasiewicz J, Williams M, Haywood A, Ellis M. The anthropocene: a new epoch of geological time? Philos Trans Roy Soc A Math Phys Eng Sci 2011, 369:835-41.

7. Chum H, Faaij A, Moreira J, Berndes G, Dhamija P, Dong H, Gabrielle B, Goss Eng A, Lucht W, Mapako M, Masera Cerutti O, McIntyre T, Minowa T, Pingoud K, Bioenergy. In: Edenhofer O, Pichs-Madruga R, Sokona Y, Seyboth K, Matschoss P, Kadner S, Zwickel T, Eickemeier P, Hansen G, Schlömer S, von Stechow C eds. IPCC Special Report on Renewable Energy Sources and Climate Change Mitigation. Cambridge/New York: Cambridge University Press; 2011.

8. Egeskog A, Berndes G, Freitas F, Gustafsson S, Sparovek G. Integrating bioenergy and food production - a case study of combined ethanol and dairy production in Pontal, Brazil. Energy Sustain Dev 2011, 15:8-16.

9. Dale BE, Bals BD, Kim S, Eranki P. Biofuels done right: land efficient animal feeds enable large environmental and energy benefits. Environ Sci Technol 2010, 44:8385-9.

10. Parish ES, Hilliard MR, Baskaran LM, Dale VH, Griffiths NA, Mulholland PJ, Sorokine A, Thomas NA, Downing ME. Multimetric spatial optimization of switchgrass plantings across a watershed. Biofuels Bioprod Biorefin 2012, 6:58-72.

11. Gopalakrishnan G, Negri MC, Salas W. Modeling biogeochemical impacts of bioenergy buffers with perennial grasses for a row-crop field in Illinois. Glob Change Biol Bioenergy 2012, 4:739-50.

12. Berndes G, Börjesson P, Ostwald M. Multifunctional biomass production systems -an overview with presentation of specific applications in India and Sweden. Biofuels Bioprod Biorefin 2008, 2:16-25.

13. Garg KK, Karlberg L, Wani SP, Berndes G. Jatropha production on wastelands in India: opportunities and trade-offs for soil and water management at the watershed scale. Biofuels Bioprod Biorefin 2011, 5:410-30.

14. Dimitriou I, Baum C, Baum S, Busch G, Schulz U, Köhn J, Lamersdorf N, Leinweber P, Aronsson P, Weih M, Berndes G, Bolte A. Quantifying environmental effects of short rotation coppice (SRC) on biodiversity, soil and water. IEA Bioenergy Task 43; 2011. Report No.: 2011:01. Available at: http://ieabioenergytask43.org/wp-content/uploads/ 2013/09/IEA_Bioenergy_Task43_TR2011-01.pdf (Accessed March 6, 2014).
15. Busch G. GIS-based Tools for Regional Assessments and Planning Processes Regarding Potential Environmental Effects of Poplar SRC. Bioenergy Res 2012, 5:584-605.

16. Gopalakrishnan G, Negri CM, Snyder S. Redesigning agricultural landscapes for sustainability using bioenergy crops: quantifying the tradeoffs between agriculture, energy and the environment. Aspect Appl Biol 2011, 112:139-46.

17. Englund O, Berndes G, Fredrikson F, Dimitriou J. Meeting sustainability requirements for src bioenergy: usefulness of existing tools, responsibilities of involved stakeholders, and recommendations for further developments. Bioenergy Res 2012, 5:606-620.

18. Junginger M, van Dam J, Zarrilli S, Ali Mohamed F, Marchal D, Faaij A. Opportunities and barriers for international bioenergy trade. Energy Policy 2011, 39:2028-2042.

19. O’Connell D, Braid A, Raison J, Handberg K, Cowie A, Rodriguez L, George B. Sustainable production of bioenergy - a review of global bioenergy sustainability frameworks and assessment systems. Australia: Rural Industries Research and Development Corporation, 2009. Available at: https://rirdc. infoservices.com.au/downloads/09-167. (Accessed September 16, 2013).

20. Stupak I, Lattimore B, Titus BD, Smith CT. Criteria and indicators for sustainable forest fuel production and harvesting: a review of current standards for sustainable forest management. Biomass Bioenergy 2011, 35:3287-308.

21. van Dam J, Junginger M, Faaij A. From the global efforts on certification of bioenergy towards an integrated approach based on sustainable land use planning. Renew Sustain Energy Rev 2010, 14:2445-72.

22. Pelkmans L, Goovaerts L, Smith CT, Joudrey J, Stupak I, Englund O, Junginger M, Goh CS, Chum H, Cowie A. Monitoring sustainability certification of bioenergy, task 4: recommendations for improvement of sustainability certified markets. EIA Bioenergy; 2013. Available at: http://www.bioenergytrade.org/ downloads/iea-sust-cert-task-4-final2013.pdf.

(Accessed September 16, 2013).

23. Goovaerts L, Pelkmans L, Goh CS, Junginger M, Joudrey J, Chum H, Smith CT, Stupak I, Cowie A, Dahlman L, Englund O, Goss Eng A. Monitoring sustainability certification of bioenergy, task 1 : examining sustainability certification of bioenergy. IEA Bioenergy; 2013. Available at: http://www.bioenergytrade. org/downloads/iea-sust-cert-task-2-final2013.pdf. (Accessed September 16, 2013).

24. Buytaert V, Muys B, Devriendt N, Pelkmans L, Kretzschmar JG, Samson R. Towards integrated sustainability assessment for energetic use of biomass: a state of the art evaluation of assessment tools. Renew Sustain Energy Rev 2011, 15:3918-33. 
25. Magar SB, Pelkonen P, Tahvanainen L, Toivonen R, Toppinen A. Growing trade of bioenergy in the EU: Public acceptability, policy harmonization, European standards and certification needs. Biomass Bioenergy 2011, 35:3318-27.

26. van Dam J, Junginger M. Striving to further harmonization of sustainability criteria for bioenergy in Europe: recommendations from a stakeholder questionnaire. Energy Policy 2011, 39:4051-66.

27. Convention on Biological Diversity. List of Parties; 2013. Available at: http://www.cbd.int/convention/ parties/list/\#tab=0. (Accessed September 16, 2013).

28. Hamilton AJ. Species diversity or biodiversity? J Environ Manage 2005, 75:89-92.

29. Secretariat of the Convention on Biological Diversity. Handbook of the Convention on Biological Diversity Including Its Cartagena Protocol on Biosafety. 3rd ed. Montreal: Secretariat of Convention; 2005.

30. Millennium Ecosystem Assessment. Ecosystems and human well-being. In: Biodiversity Synthesis. Washington, DC: World Resources Institute; 2005. Available at: http://www.maweb.org/documents/document.354. aspx.pdf. (Accessed September 16, 2013).

31. Miller G. Living in the Environment: Principles, Connections, and Solutions. 15th ed. Belmont CA: Thomson Brooks/Cole; 2007.

32. Bisby F. Characterization of biodiversity. In: Heywood VH, Watson RT, eds. Global Biodiversity Assessment. Cambridge: The United Nations Environment Programme and Cambridge University Press; 1995, 21-106.

33. Heywood VH, Baste I. Introduction. In: Heywood VH, Watson RT, eds. Global Biodiversity Assessment. Cambridge: The United Nations Environment Programme and Cambridge University Press; 1995, 1-19.

34. Namkoong G, Boyle T, Gregorius H, Joly H. Testing criteria and indicators for assessing the sustainability of forest management: genetic criteria and indicators. Working paper No. 10. Bogor, Indonesia: CIFOR; 1996.

35. Cadotte MW, Carscadden K, Mirotchnick N. Beyond species: functional diversity and the maintenance of ecological processes and services. J Appl Ecol 2011, 48:1079-1087.

36. Leibold MA, McPeek MA. Coexistence of the niche and neutral perspectives in community ecology. Ecology 2006, 87:1399-1410.

37. Scherr SJ, McNeely JA. Biodiversity conservation and agricultural sustainability: towards a new paradigm of “ecoagriculture" landscapes. Philos Trans R Soc Lond B Biol Sci 2008, 363:477-94.

38. Wu J. Landscape ecology, cross-disciplinarily, and sustainability science. Landsc Ecol 2006, 21:1-4.

39. Daily G, Ehrlich P, Sánchez-Azofeifa GA. Countryside biogeography: use of human-dominated habitats by the avifauna of southern Costa Rica. Ecol Appl 2001, 11:1-13.

40. Dushku A, Brown S, Pearson T, Shoch D, Howley B. Remote sensing. In: Scherr SJ, McNeely JA, eds. Farming with Nature: The Science and Practice of Ecoagriculture. Washington DC: Island Press; 2007.

41. Sverdrup-Thygeson A, Borg P, Bergsaker E. A comparison of biodiversity values in boreal forest regeneration areas before and after forest certification. Scand J Forest Res 2008, 23:236-43.

42. Wintle BA, Lindenmayer DB. Adaptive risk management for certifiably sustainable forestry. For Ecol Manage 2008, 256:1311-9.

43. Karsenty A, Gourlet-Fleury S. Assessing sustainability of logging practices in the Congo Basin's managed forests: the issue of commercial species recovery. Ecol Soc 2006, 11(1):26. Available at: http:// www.ecologyandsociety.org/vol11/iss1/art26/. (Accessed September 16, 2013).

44. Zapf R, Schultheiss U, Doluschitz R. Assessment of sustainability - common requirements and comparative evaluation of the systems RISE, KSNL and the "DLG certification system for sustainable agriculture". Ber Landwirtsch 2009, 87:402-427.

45. Koskela E, Ollikainen M, Pukkala T. Biodiversity conservation in commercial boreal forestry: the optimal rotation age and retention tree volume. Forest Sci 2007, 53:443-452.

46. Dennis RA, Meijaard E, Nasi R, Gustafsson L. Biodiversity conservation in Southeast Asian timber concessions: a critical evaluation of policy mechanisms and guidelines. Ecol Soc 2009, 13:25. Available at: http:// www.ecologyandsociety.org/vol13/iss1/art25/.

(Accessed September 16, 2013).

47. Bisseleua DHB, Missoup AD, Vidal S. Biodiversity conservation, ecosystem functioning, and economic incentives under cocoa agroforestry intensification. Conserv Biol 2009, 23:1176-84.

48. Felton A, Wood J, Felton AM, Hennessey B, Lindenmayer DB. Bird community responses to reduced-impact logging in a certified forestry concession in lowland Bolivia. Biol Conserv 2008, 141: $545-555$.

49. Johansson J, Lidestav G. Can voluntary standards regulate forestry?-assessing the environmental impacts of forest certification in Sweden. Forest Policy Econ 2011, 13:191-198.

50. Wiersum KF, Gole TW, Gatzweiler F, Volkmann J, Bognetteau E, Wirtu O. Certification of wild coffee in Ethiopia: experiences and challenges. Forests Trees Liveliboods 2008, 18:9-21.

51. Clark M, Kozar J. Comparing sustainable forest management certifications standards: a meta-analysis. Ecol Soc 2011, 16:3. Available at: http://www. ecologyandsociety.org/vol16/iss1/art3/. (Accessed September 16, 2013). 
52. Ioras F, Abrudan IV, Dautbasic M, Avdibegovic M, Gurean D, Ratnasingam J. Conservation gains through HCVF assessments in Bosnia-Herzegovina and Romania. Biodivers Conserv 2009, 18:3395-3406.

53. Lattimore B, Smith CT, Titus BD, Stupak I, Egnell G. Environmental factors in woodfuel production: opportunities, risks, and criteria and indicators for sustainable practices. Biomass Bioenergy 2009, 33:1321-1342.

54. Gove AD, Hylander K, Nemomisa S, Shimelis A. Ethiopian coffee cultivation-implications for bird conservation and environmental certification. Conserv Lett 2008, 1:208-216.

55. Philpott SM, Bichier P, Rice R, Greenberg R. Field-testing ecological and economic benefits of coffee certification programs. Conserv Biol 2007, 21:975-85.

56. Garrelts H, Flitner M. Governance issues in the ecosystem approach: what lessons from the Forest Stewardship Council? Eur J Forest Res 2011, 130:395-405.

57. Elbakidze M, Angelstam P, Andersson K, Nordberg M, Pautov Y. How does forest certification contribute to boreal biodiversity conservation? Standards and outcomes in Sweden and NW Russia. For Ecol Manage 2011, 262:1983-95.

58. Miller DA, Wigley TB, Miller KV. Managed forests and conservation of terrestrial biodiversity in the southern United States. J Forest 2009, 107:197-203.

59. Hickey GM, Nitschke CR. Monitoring sustainable forest management in the Pacific Rim Region. J Sustain Forest 2007, 24:245-78.

60. Marjokorpi A, Salo J. Operational standards and guidelines for biodiversity management in tropical and subtropical forest plantations - how widely do they cover an ecological framework? Silva Fenn 2007, 41:281-297.

61. Suzuki N, Olson DH. Options for biodiversity conservation in managed forest landscapes of multiple ownerships in Oregon and Washington, USA. Biodivers Conserv 2008, 17:1017-39.

62. Visseren-Hamakers IJ, Glasbergen P. Partnerships in forest governance. Glob Environ Chang 2007, $17: 408-19$.

63. Anand MO, Krishnaswamy J, Das A. Proximity to forests drives bird conservation value of coffee plantations: implications for certification. Ecol Appl 2008, 18:1754-63.

64. McGeoch MA, Schroeder M, Ekbom B, Larsson S. Saproxylic beetle diversity in a managed boreal forest: importance of stand characteristics and forestry conservation measures. Divers Distrib 2007, 13:418-29.

65. Lõhmus A, Kraut A. Stand structure of hemiboreal old-growth forests: characteristic features, variation among site types, and a comparison with FSC-certified mature stands in Estonia. For Ecol Manage 2010, 260:155-165.
66. Marchai D, Stappen F, Schenkel Y. Sustainable production criteria and indicators for solid biofuels. Biotechnol Agron Soc Environ 2009, 13:165-176.

67. Lagan P, Mannan S, Matsubayashi H. Sustainable use of tropical forests by reduced-impact logging in Deramakot Forest Reserve, Sabah, Malaysia. Ecol Res 2007, 22:414-21.

68. Eriksson S, Hammer M. The challenge of combining timber production and biodiversity conservation for long-term ecosystem functioning-a case study of Swedish boreal forestry. For Ecol Manage 2006, 237:208-217.

69. Smeets EM, Faaij AP. The impact of sustainability criteria on the costs and potentials of bioenergy production-applied for case studies in Brazil and Ukraine. Biomass Bioenergy 2010, 34:319-33.

70. Hennenberg KJ, Dragisic C, Haye S, Hewson J, Semroc B, Savy C, Wiegmann K, Fehrenbach H, Fritsche UR. The power of bioenergy-related standards to protect biodiversity. Conserv Biol 2010, 24:412-23.

71. Smeets E, Junginger M, Faaij A, Walter A, Dolzan P, Turkenburg W. The sustainability of Brazilian ethanol-an assessment of the possibilities of certified production. Biomass Bioenergy 2008, 32:781-813.

72. Zedler PH, Anchor T, Knuteson D, Gratton C, Barzen J. Using an ecolabel to promote on-farm conservation: the Wisconsin Healthy Grown experience. Int J Agric Sustain 2009, 7:61-74.

73. Tejeda-Cruz C, Silva-Rivera E, Barton JR, Sutherland WJ. Why shade coffee does not guarantee biodiversity conservation. Ecol Soc 2013, 15:13. Available at: http://www.ecologyandsociety.org/vol15/iss1/art13/. (Accessed September 16, 2013).

74. Timonen J, Siitonen J, Gustafsson L, Kotiaho JS, Stokland JN, Sverdrup-Thygeson A, Mönkkönen M. Woodland key habitats in northern Europe: concepts, inventory and protection. Scand J Forest Res 2010, 25:309-24.

75. FSC. FSC principles and criteria for Forest Stewardship: FSC-STD-01-001 (version 4-0). Bonn, Germany: Forest Stewardship Council; 2002. Available at: https://ca.fsc.org/download.principles-criteria-v4.7. pdf. (Accessed September 16, 2013).

76. SFI. Requirements for the SFI 2010-2014 Program. Standards, Rules for Label Use, Procedures and Guidance. Washington DC: Sustainable Forestry Initiative; 2010. Available at: http://www.sfiprogram. org/files/pdf/sfirequirements2010-2014pdf/. (Accessed September 16, 2013).

77. FFCS. FFCS 1002-3:2003, criteria for certification of holdings of individual forest owners. Unofficial Translation (3 February 2004) of the Original Finnish Standard FFCS 1002-3:2003 text. Helsingfors: Finnish Forest Certification System; 2004. Available at: http://www.pefc.fi/media/Standardit/FFCS_1002_3_ 2003ENG.pdf. (Accessed September 16, 2013). 
78. MTCC. Malaysian Criteria and Indicators for Forest Management Certification [MCl\&I(2002)]. Kuala Lumpur: Malaysian Timber Certification Council; 2002.

79. MTCC. Malaysian Criteria and Indicators for Forest Management Certification (Forest Plantations) [MCl\&I(Forest Plantations)]. Kuala Lumpur: Malaysian Timber Certification Council; 2008. Available at: http://www.mtcc.com.my/wp-content/ uploads/2013/01/21.pdf. (Accessed September 16, 2013).

80. CSA. Sustainable Forest Management Z809-08. Mississauga, Canada: Canadian Standards Association; 2010. Available at: http://www.csagroup. org/documents/codes-and-standards/publications/ 2419617.pdf. (Accessed September 16, 2013).

81. GGL. GGLS5 - Forest Management Criteria. Zwolle, The Netherlands: Green Gold Label; 2010. Available at: http://www.greengoldcertified. org/data/docs/ggl5.pdf. (Accessed September 16, 2013).

82. Naturland. Naturland Standards for Organic Forest Management. Gräfelfing, Germany: Naturland; 1998. Available at: http://www.naturland.de/ fileadmin/MDB/documents/Richtlinien_englisch/ Naturland-Standards-Organic-forest-management_ 1998-11.pdf. (Accessed September 16, 2013).

83. ITTO. Revised ITTO criteria and indicators for the sustainable management of tropical forests, including reporting format. ITTO Policy Development Series No 15. Yokohama: International Tropical Timber Organization; 2005. Available at: http://www.itto.int/direct/ topics/topics_pdf_download/topics_id=9630000\& no=1. (Accessed September 16, 2013).

84. ATO/ITTO. ATO/ITTO principles, criteria and indicators for the sustainable management of African natural tropical forests. ITTO Policy Development Series No 14. Yokohama/Libreville: African Timber Organization and International Tropical Timber Organization; 2003. Available at: http://www.itto.int/direct/ topics/topics_pdf_download/topics_id=1550000\& no=1. (Accessed September 16, 2013).

85. ITTO/IUCN. ITTO/IUCN Guidelines for the conservation and sustainable use of biodiversity in tropical timber production forests. ITTO Policy Development Series No 17. Yokohama/Gland: International Tropical Timber Organization and International Union for Conservation of Nature; 2009. Available at: http:// www.itto.int/direct/topics/topics_pdf_download/ topics_id=1918\&no=0. $\quad($ Accessed September 16, 2013).

86. MCPFE. Annex 1 of the Resolution L2: Pan-European criteria and indicators for sustainable forest management. In: Ministerial Conference on the Protection of Forests in Europe; 1998. Available at: http://www. foresteurope.org/docs/MC/MC_lisbon_resolution_ annex1.pdf. (Accessed September 16, 2013).
87. MCPFE. Improved Pan-European Indicators for Sustainable Forest Management. In: Ministerial Conference on the Protection of Forests in Europe; 2002. Available at: http://www.foresteurope. org/docs/reporting/Vienna_Improved_Indicators.pdf. (Accessed September 16, 2013).

88. GlobalGAP. Integrated farm assurance - all farm base. Control Points and Compliance Criteria. Version 4.0, Ed. 4.0-1\_FEB2012. Cologne, Germany: GlobalGAP; 2011.

89. GlobalGAP. Integrated farm assurance - crops base. Control Points and Compliance Criteria. Version 4.0, Ed. 4.0-1\_FEB2012. Cologne, Germany: GlobalGAP.; 2011.

90. GlobalGAP. Integrated farm assurance - combinable crops. Control Points and Compliance Criteria. Version 4.0, Ed. 4.0-1\FEB2012. Cologne, Germany: GlobalGAP; 2011.

91. KRAV. Regler för KRAV-certifierad produktion januari 2011. Uppsala, Sweden: KRAV; 2011.

92. European Council. Council Regulation (EC) No $834 / 2007$ of 28 June 2007 on organic production and labelling of organic products and repealing Regulation (EEC) No 2092/91. Brussels: European Council; 2007. Available at: http://eur-lex.europa.eu/LexUriServ/ LexUriServ.do?uri=OJ:L:2007:189:0001:0023:EN: PDF. (Accessed September 16, 2013).

93. European Commission. Commission Regulation (EC) No 1235/2008 of 8 December 2008 laying down detailed rules for implementation of Council Regulation (EC) No 834/2007 as regards the arrangements for imports of organic products from third countries. Brussels: European Commission; 2008. Available at: http://eur-lex.europa.eu/LexUriServ/LexUriServ.do? uri=OJ:L:2008:334:0025:0052:EN:pdf. (Accessed September 16, 2013).

94. European Commission. Commission Regulation (EC) No 889/2008 of 5 September 2008 laying down detailed rules for the implementation of Council Regulation (EC) No 834/2007 on organic production and labelling of organic products with regard to organic production, labelling and control. Brussels: European Commission; 2008. Available at: http://eurlex.europa.eu/LexUriServ/LexUriServ.do?uri=OJ: L:2008:250:0001:0084:EN:PDF. (Accessed September 16, 2013).

95. USDA. 7 C.F.R. Part 205: National Organic Program Regulations. Washington DC: United States Department of Agriculture; 2000. Available at: http://www. ecfr.gov/cgi-bin/text-idx?c=ecfr\&sid=3f34f4c22f9aa 8e6d9864cc2683cea02\&tpl=/ecfrbrowse/Title07/ 7cfr205_main_02.tpl. (Accessed September 16, 2013).

96. GGL. GGLS2 - Agricultural Source Criteria. Zwolle, The Netherlands: Green Gold Label; 2010. Available at: http://www.greengoldcertified.org/data/docs/ ggl2.pdf. (Accessed September 16, 2013). 
97. FLO International. Fairtrade Standard for Small Producer Organizations. Version: 01.05.2011. Bonn, Germany: FLO International; 2011. Available at: http:// www.fairtrade.net/fileadmin/user_upload/content/ 2009/standards/documents/2012-07-11_SPO_EN.pdf. (Accessed September 16, 2013).

98. Naturland. Naturland Standards on Production. Gräfelfing, Germany: Naturland; 2011. Available at: http://www.naturland.de/fileadmin/MDB/ documents/Richtlinien_englisch/Naturland-StandardsOrganicforest-management_1998-11.pdf. (Accessed September 16, 2013).

99. IFOAM. The IFOAM Norms for Organic Production and Processing, Version 2005. Bonn, Germany: International Federation of Organic Agriculture Movements; 2005.

100. SAN. Sustainable Agriculture Standard. July 2010 (version 2). San José: Sustainable Agriculture Network/Rainforest Alliance; 2010. Available at: http:// sanstandards.org/userfiles/file/SAN\%20Sustainable \% 20Agriculture \%20Standard\%20July\%202010.pdf. (Accessed June, 2012).

101. RSPO. RSPO Principles and Criteria for Sustainable Palm Oil Production, Including Indicators and Guidance. October 2007. Kuala Lumpur: Roundtable on Sustainable Palm Oil; 2007. Available at: http://www.rspo.org/files/resource_centre/RSPO $\% 20$ Principles \%20\&\%20Criteria\%20Document.pdf. (Accessed September 16, 2013).

102. RTRS. RTRS Standard for Responsible Soy Production Version 1.0. Buenos Aires: Roundtable on Responsible Soy; 2010. Available at: http://www.responsiblesoy. org/index.php?option $=$ com_docman \&task $=$ doc download\&gid=290\&Itemid=19\&lang=en . (Accessed September 16, 2013).

103. RTRS. RTRS EU RED Compliance Requirements for Producers. Version 3.0 \_EN. Buenos Aires: Roundtable on Responsible Soy; 2011. Available at: http://www.responsiblesoy.org/index.php?option= com_docman\&task $=$ doc_download $\&$ gid $=654 \&$ Itemid=63\&lang=en. (Accessed September 16, 2013).

104. Bonsucro. Bonsucro Production Standard, Including Bonsucro EU Bonsucro Production Standard. London: Bonsucro; 2011. Available at: http://www. bonsucro.com/assets/Bonsucro_Production_Standard_ March_2011_3.pdf. (Accessed September 16, 2013).
105. RSB. Consolidated RSB EU RED Principles $\ \&$ Criteria for Sustainable Biofuel Production. Geneva, Switzerland: Roundtable on Sustainable Biofuels; 2011. Available at: http://rsb.org/pdfs/standards/ RSB-EU-RED-Standards/11-05-10-RSB-STD-11-00101-001-vers-2-0-Consolidated-RSB-EU-RED-PCs.pdf. (Accessed September 16, 2013).

106. RSB. Indicators of Compliance for the RSB EU RED Principles I\& Criteria. Geneva: Roundtable on Sustainable Biofuels; 2010. Available at: http:// rsb.org/pdfs/standards/11-03-08-RSB-PCs-Version-2. pdf. (Accessed September 16, 2013).

107. ISCC. Sustainability requirements for the production of biomass: ISCC 11-03-15 V 2.3-EU. Cologne, Germany: International Sustainability \& Carbon Certification; 2011. Available at: https://www.cbh. com.au/media/300335/iscc\%20202\%20sustainability \%20requirements.pdf. (Accessed September 16, 2013).

108. Greenergy. Greenergy Brazilian Bioethanol verification programme: Greenergy bioethanol sustainability criteria for Brazilian sugarcane STD DOC - 002 v.5 31 January 2011. London: Greenergy; 2011. Available at: http://ec.europa.eu/energy/renewables/biofuels/ sustainability_schemes_en.htm. (Accessed September 16, 2013).

109. Trombulak SC, Omland KS, Robinson JA, Lusk JJ, Fleischner TL, Brown G, Domroese M. Principles of conservation biology: recommended guidelines for conservation literacy from the education committee of the society for conservation biology. Conserv Biol 2004, 18:1180-90.

110. Millenium Ecosystem Assessment. Ecosystems and Human Well-being: Current State and Trends, Volume. Washington, DC: Island Press; 2013. Available at: http://www.maweb.org/documents/document.273. aspx.pdf. (Accessed September 16, 2013).

111. Soule M. What is conservation biology. BioScience 1985, 35:727-34.

112. TMUG - ToSIA Management and User Group. Tool for Sustainability Impact Assessment. Joensuu, Finland: European Forest Institute; 2013. Available at: http://www.northerntosia.org/files/attachments/ northerntosia/final_conference/final_copy_n_tosia_ general_flier.pdf (Accessed March 6, 2014). 